\title{
The International Literature on Skills Training and the Scope for South African Application
}

\author{
Sean Archer \\ School of Economics \\ University of Cape Town \\ sean.archer@uct.ac.za
}

Development Policy Research Unit

DPRU Working Paper 07/124

ISBN Number: 978-1-920055-47-9

July 2007 


\section{Abstract}

This paper aims to introduce selected issues from the international literature on skills training into the South African policy forum. Reform of national strategies in skills production has characterised a number of industrial as well as certain developing economies in recent decades. Their experience is potentially valuable locally.

The main lessons are that skills training resembles education in being partly a public good. The acquisition of skills parallels the acquisition of knowledge. Training opportunities do have to be rationed by some mechanism, either through the market or by rules internal to an organisation engaged in training, but the content of the competency learned is a form of knowledge. More competency with economic value that is acquired by one person does not mean less of it is available for acquisition by another. Nor, secondly, can non-payers be wholly excluded from the benefits of training financed by others. For example, there are separate gains for fellow workers, for employers poaching trained workers, and for investors in new technology. So certain economic decision-takers can free-ride on such investments in human capital. As classic examples of market failure they make clear that simple allocation through a market is not at all adequate for a national system of skills training.

The second lesson is that problems of information, incentives and market power preclude the emergence of a training equilibrium in which individual workers and employers pursue their interests successfully and therefore efficiently. In practice most training takes place on the job, where it is difficult for an outside agency like the state to influence investment decisions directly. Sensible roles for the state are to supply needed information, to put in place positive and negative incentives where needed, to provide accreditation that is credible in the market, to set up a framework of regulation that fosters informational transparency and constrains skills poaching, and to invest in high quality prior education for trainees entering occupational markets. An additional state function is to provide

workable policy devices like 'temporary migration programmes' that enable active skilled labour recruitment from source countries. International precedents exist that show the way in a number of these expedients. 


\section{Acknowledgement}

I am indebted to a number of people for suggestions and for information, in particular Murray Leibbrandt, Ingrid Woolard and Paul Lundall.

\section{Glossary}

DoL

- $\quad$ Department of Labour

FET

- $\quad$ Further Education and Training

GDP

- $\quad$ Gross Domestic Product

HE

- $\quad$ Higher Education

HSRC

- Human Sciences Research Council

NSDS

- $\quad$ National Skills Development Strategy

OJT

- $\quad$ On-the-Job-Training

SASOL

- $\quad$ Originally - Suid Afrikaanse Steenkool en Olie

(South African Coal and Oil)

$\begin{array}{lll}\text { SETA } & - & \text { Sector Education and Training Authority } \\ \text { SSP } & - & \text { Sector Skills Plan } \\ \text { TMPs } & - & \text { Temporary Migration Programmes }\end{array}$

Development Policy Research Unit Tel: +27216505705

Fax: +27 216505711
Information about our Working Papers and other published titles are available on our website at: http://www.commerce.uct.ac.za/dpru/ 


\section{Table of Contents}

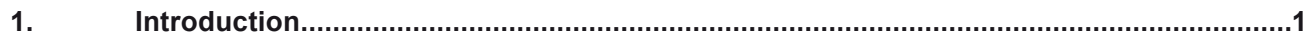

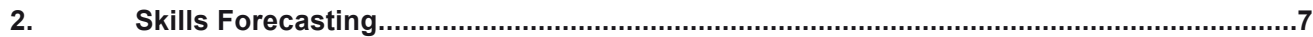

3. Theoretical Developments in the Economics of Skills Training ...................................18

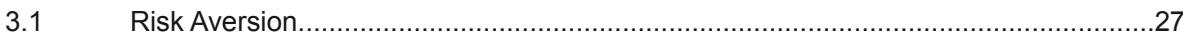

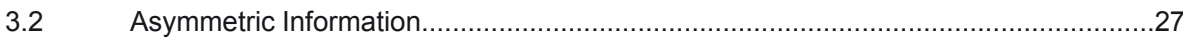



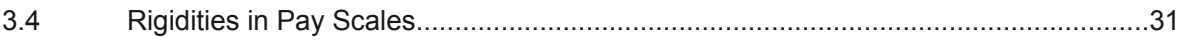

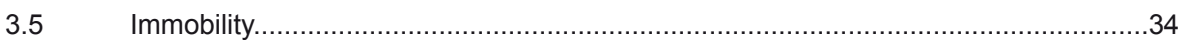

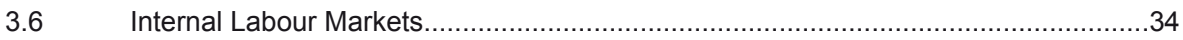

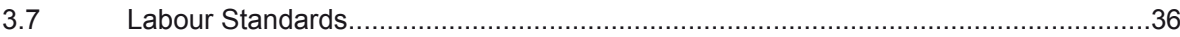

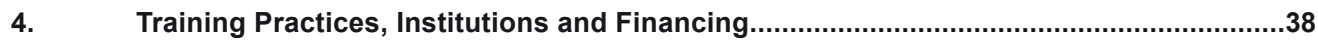

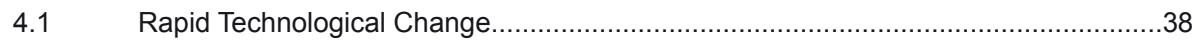



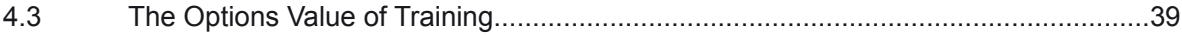

S.4 Social Expectations on Training Provision............................................................40

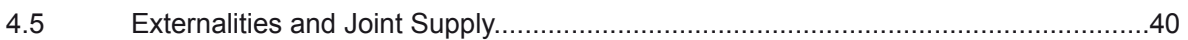

4.6 Exporting Training Institutions and Substituting Functional Equivalents....................41

4.7 Constraining the Turnover of Skilled Labour..................................................43

4.8 Risk Pooling and Insurance Possibilities..................................................44

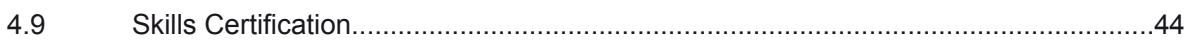



4.11 Skills as Complements to Research and Development Investment........................47



S.13 State Loan Guarantees and their Hazards........................................................49

5. Potential Problems in South African Application......................................................51

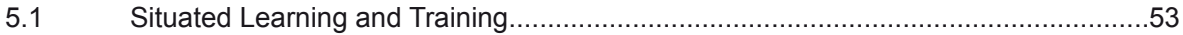

5.2 Training as a Necessary but not Sufficient Condition for Job Creation......................55

5.3 The Potential Conflict between Training Objectives................................................56

5.4 The Monitoring Problems that Face State Initiatives in On-The-Job

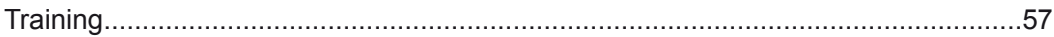

5.5 System that Works as a System................................................................

6. High Level Skills Production in Tertiary Education................................................62

7. Skills Importation and a South African Skills Training Equilibrium................................68

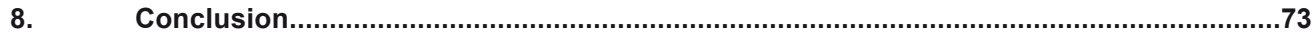




\section{Introduction}

The policy debate over skills training in South Africa in the past one to two decades has been conducted largely without an adequate research base. The main contention of this paper is that pointers to such a base lie in the international literature. It contains discussed themes, sets investigation objectives and makes explicit presumptions that for the most part do not appear in local policy-oriented research work. Why this should be so is not easy to answer. For instance, it may be that an over-riding concern with equity and the necessity of reversing past discriminatory access to skills training has tended to push into the background the underlying investment requirements for every efficient act of skills acquisition. Being efficient is usually beneficial jointly to trainee and employer. Yet equity and efficiency goals may not be easily combined in a single strategic instrument. For the present this is speculation, not resting on secure research foundations. It is thus one of the main questions from a policy perspective, and it is certainly necessary to untangle in order to make progress in skills production.

The separation of education from training is a first instance of inadequate conceptualisation. This has become embedded in the policy arena despite the fact that the division between the two for policy purposes possesses only an institutional identity. Education takes place in schools, skills training takes place in the workplace or specialised institutions like FET colleges, two sets of institutions which operate and are governed differently. Thus, it is not a question of the underlying conceptual or even logical distinction between two investment activities that justifies separate research efforts. This bifurcation in the study of labour force characteristics is surprising given that the majority of school-leavers enter the labour market directly and do not go on to additional education or vocational training. It is curious why they receive so little research attention as economically active citizens when all they have with which to perform paid work are their school-acquired competencies. In the literature these are called "basic skills [by which] we mean the levels of basic numeracy and literacy that are recognised as the minimum required to perform in today's labour market, and indeed in the world in general"? (Mclntosh \& Vignoles 2001: 453)

A second illustration of research that is wanting is that the enquiries into skills training that have taken place locally have focused on problems at an undesirably aggregated level. The Department of Labour (DoL) and the Human Sciences Research Council (HSRC), for instance, tend to monitor and measure training by sector, by designated employee group, by broad occupation or accredited skill category, by size of firm, and so on. What 
is neglected is research at the individual decision level where net investment in training is determined positively or negatively, as the case may be. One serious consequence is that too little attention is paid to cost and productivity, to rate of return and to profitability. All these variables depend on the fundamental relationship between the resulting change in productivity and the changed payment made to the newly skilled worker after training. The behaviour of wages and profits before and after training provide virtually the only signals there are to track these consequences of investment decisions. But, unless these variables are examined closely we cannot obtain a measure of the increased output of a labour skill that becomes ready for the production process. This is the crucial magnitude to the employer who makes most decisions about the nature, provision and funding of training.

Thirdly, as a final illustration of the incomplete research base, it has become clear that estimates of skills shortages obtained by simple questionnaires addressed to a sample of employers in an industry or sector (sector as defined specifically for SETA purposes) need careful evaluation. It is not at all persuasive that employer answers of stated skill needs are true effective demands; that is, what they would be prepared to pay in hiring an extra skilled worker. The relevant question should be couched along lines like "How many additional newly skilled workers would your firm employ at the average starting wage and non-wage benefits ruling in the occupational market for that skill?" Responses to specified questions like this might confirm existing estimates; but equally they may well turn out to be markedly lower than the answers quoted in industry surveys, for instance, like that conducted for the petroleum and chemical industry by SASOL (2004).

As the means to allocate workers to jobs and jobs to workers, the labour market is the only serious alternative we have. With the downfall of the centrally-planned economies, it is the only set of institutions which, together with interventionist actions by political authority, has the potential to generate as well as administer human resources satisfactorily in contemporary economies. With that in mind, investment in human capital via training is the concern of this paper. More specifically it addresses the theoretical framework for examining the finance and organisation of such investment, the identification of the needed institutions, and the perspective which the international literature provides for the problems that face South Africa's National Skills Development Strategy (NSDS), now in its second phase. 
A second point of orientation concerns the question of exportability between countries of training institutions and policy interventions by government. It is unrealistic a priori to expect one set of practices in the finance and delivery of training to fit the existing range of national circumstances. Table 1 gives an idea of the alternative systems to be found in industrial countries. These are best thought of as forms of training equilibrium in which decisiontakers - employers, workers, training providers, and the state - can pursue their skill goals successfully. These variations in international practice are essential to note because it means that every structure of training provision must adapt to a spectrum of features in the national environment, which at a minimum must encompass the following (shown schematically in Tables 1 and 2):

a) The education system in this context refers specifically to its output of basic skills as they are labelled in the training literature, and to the aptitudes of the principal groups that demand training at any one time. In broad categories these are labour force entrants who exit from school into the labour market at different levels of achievement; the proportion of these school-leavers who go on to higher or vocational education; the mature workers lacking skills in their own estimation or with acquired skills no longer in demand; the self-employed; and the unemployed. Clearly from a policy perspective itmakes no sense to compartmentalise formal education as a sphere of skill formation separate from the others that exist.

b) The organisation and functioning of the labour market itself, noting its sectoral, regional and economy-wide characteristics. (i) Occupational labour markets for particular kinds of skill are subdivisions within the national labour market. Other relevant variables are, for instance. (ii) the proportion of companies which operate internal markets within the organisation for different skilled functions and responsibilities rather than relying on external skill markets; (iii) the capacity of payment systems to adapt readily to supply and demand pressures; (iv) the conduct of industrial relations, notably the extent to which training provision is subject to collective bargaining agreements, to co-determination between employer and employee, and to wage compression; and (v) the relationship between the certification of acquired skills and the employability of the trained worker. Even the nature of work organisation and technical change are relevant insofar as these spur employers under competitive pressure into hiring new skills or to undertake training 
c) There are features of the capital market that govern the financial transactions required for investments in skill acquisition by individuals and companies. Credit constraints on individual workers that inhibit their borrowing for investment in training are a standard source of market failure identified in the literature. However, the supporting evidence for this failure in certain industrial countries is considered mixed and therefore weak (Carneiro \& Heckman 2003; Heckman \& Masterov 2004). Although this ambiguity of the evidence may not apply to a developing country's credit market where the constraint on the supply of loans may exert a major inhibiting influence on individual initiatives to acquire new skills. There is no local loan fund for the acquisition of intermediate skills which parallels the National Student Financial Aid Scheme for tertiary level degrees and diplomas. In South Africa this entire question of borrowing constraints is currently an important research task that awaits attention.

d) The organisation and financing of training by firms, collective institutions like SETAs and state agencies is the central concern of every initiative to raise the pace of skills investments. Here we must bear in mind the fundamental distinction between the provision of training and the ultimate payment for it, because in economic terms it is a commodity with mixed private and public good characteristics. This distinction is explained below in the main body of the discussion, but its main implication is that markets alone cannot allocate training resources efficiently.

In summary, this paper chooses a set of themes from the current international literature on the economics of skills training with an eye to their South African application. Thereby it provides suggestions for further policy formation and adaptation. There is no attempt at completeness, but we would be surprised if there are issues of major importance that fail to be discussed here. 
Table 1: Alternative Training Systems

\begin{tabular}{|c|c|c|}
\hline System & Country & Basic Characteristics/lssues \\
\hline Apprenticeship Training & $\begin{array}{l}\text { Germany, United Kingdom (pre- } \\
\text { 1980) and the Netherlands }\end{array}$ & $\begin{array}{l}\text { - Co-determination (employers, unions } \\
\text { and government) } \\
\text { - Co-investment } \\
\text { - Certification of skills } \\
\text { - Incentives for all to do well in school }\end{array}$ \\
\hline $\begin{array}{l}\text { Low employee turnover and } \\
\text { extensive training }\end{array}$ & Japan & $\begin{array}{l}\text { - Lifetime employment } \\
\text { - Firms provide general and specific } \\
\text { company training } \\
\text { - Training embedded in production } \\
\text { process } \\
\text { - High degree of homogeneity in literacy } \\
\text { and numeracy }\end{array}$ \\
\hline Government-led / school-based & $\begin{array}{l}\text { Sweden, Norway, United Kingdom } \\
\text { (post-1980) }\end{array}$ & $\begin{array}{l}\text { - Government-funded general training } \\
\text { - Government may also fund firm-specific } \\
\text { training } \\
\text { - Relevance of school-based programs }\end{array}$ \\
\hline Employer training Tax & France, Australia & $\begin{array}{l}\text { - Distributes costs over wide range of } \\
\text { Employers } \\
\text { - Does not guarantee training of unskilled } \\
\text { and those in small firms }\end{array}$ \\
\hline $\begin{array}{l}\text { School-based / learning-by- } \\
\text { doing }\end{array}$ & United States, Canada & $\begin{array}{ll}\text { - } & \text { Individual autonomy on training } \\
\text { - } & \text { Investments } \\
\text { - } & \text { Multiple sources of training } \\
\text { - } & \text { Few nationally recognized qualifications } \\
\text { outside formal schooling } \\
\text { - Employer training is primarily firm } \\
\text { Specific }\end{array}$ \\
\hline
\end{tabular}

Source: Lynch (1994: 7) 
Table 2: Simplified Three Stages Training Model

\begin{tabular}{|c|c|}
\hline Pre-entry Outcome & Training Stage \\
\hline School-leaving qualifications obtained & $\begin{array}{l}\text { - } \\
\text { - } \\
\text { - On-site delivery } \\
\text { Off-site delivery }\end{array}$ \\
\hline Pre-vocational Employment Education & $\begin{array}{l}\text { - Finance: costs and benefits after training } \\
\text { - Co-ordination by state, employers, unions }\end{array}$ \\
\hline
\end{tabular}

Source: Rose (1991: 78) 


\section{Skills Forecasting}

From the date of its launch the National Skills Development Strategy has included the construction of skills plans at workplace, sector and national levels. In recent times skills planning at the national level appears to have shifted down the action agenda for reasons not made clear in official documentation.

Skills forecasting is subject to unknown margins of error and is no longer practiced widely internationally. In general the literature is skeptical after the disappointed hopes for developing country man-power planning exercises conducted in the 1970s (ILO 1995; Heijke 1994; Hopkins 2002; Ellis 2003; Woolard, Kneebone \& Lee 2003). Yet the designers of South Africa's NSDS appeared to believe in the late 1990s that the jury was still out on the matter, so they made projections of skill needs a cornerstone of the new policy. The potential pitfalls can be summarised under headings like the '3-Ts': tastes or preferences of consumer as well as investor decision-takers; technology; and trade. For any skills plan to convey useful information, these dimensions must be presumed to remain sufficiently static over all meaningful forecast periods. Only then would future skills profiles of any accuracy or realism be obtainable.

Such forecasting difficulties appear to exist in all national labour markets.

As long ago as 1989 the main [UK] national employers body - the Confederation of British Industry (CBI) - argued that "few employers are able to predict their medium term skill requirements with any confidence. The uncertainties over technology, exchange rates, and future corporate strategies are simply too great to allow traditional corporate manpower planning approaches to work effectively". Many of these factors have with the passage of time become more, not less, uncertain (Gleeson \& Keep 2004: 56).

The subject of forecasting is large, so broad observations must suffice here to show the underlying uncertainties. For instance, freeing up international capital flows and the increasing globalisation of trade in recent decades have significantly widened the range of goods and services bought and sold in domestic commodity markets. Similarly, sites of production that can be located in more than one national territory are thus subject to a wider range of site choice. In consequence it seems that changes in tastes have accelerated with accompanying alterations in the mix and availability of consumption 
and investment goods; although the causes of such changes are not easy to identify (Acemoglu 2002; Crafts 2004; Rodrik 2004). So the pattern of productive skills in demand has to alter in step with such compositional changes in output, making the forecast of skill requirements subject to ever wider error margins.

The second obstacle to effective forecasting is the relationship between technological change and the associated human capital inputs. This linkage is similarly complex and not amenable to generalisation. The key unknowns are the substitution possibilities within any given technique of production in use. Substitution refers to the flexibility or, at the alternative end of the spectrum, the fixity of input coefficients per unit of output; that is, how much skilled labour, unskilled labour, capital and so on is required for each unit of production. This is most fruitfully viewed in relative terms. At one extreme, complete fixity is an assumption of the Leontief-type production function used in the input-output analysis of a given structure of sectoral or economy-wide production. But, in such applications there is no agreement on the extent to which such assumed fixity is analytically convenient but of unknown accuracy in actual production.

One large American study some years ago was emphatic about the major unknowns that attach to the characteristics of technology and its governing of skills demand. Still widely cited, it embodies the skeptical position on skills forecasting that has emerged in recent decades.

The conclusions of this research [on the effects of technological change on the skill requirements of employmentand the distribution of earnings] are subject to such enormous uncertainties that policy-makers concerned with training and education are well advised to avoid large resource commitments to any specific vision of the detailed occupational structure and skill requirements of the future US economy... a study by Binkin of the US military's experience in forecasting and adapting to the changing skill requirements of new weapons systems... [shows that the military authorities have] been remarkably unsuccessful. Even within an environment in which the design and introduction of new technological systems and the training of personnel to operate these systems are largely controlled by a single organization, the skill impacts of new technologies have created severe difficulties for policymakers. (Cyert \& Mowery 1988: xviii-xxix, emphasis added). 
Recent thinking about technology transfer between different economies, as well as about the adaptation and assimilation of new production techniques in the receiving economy, has introduced the concept of tacit capability, brought out in the quotation below.

M]uch of the knowledge about how to perform elementary processes and about how to combine them in efficient systems is tacit, not feasibly embodied and neither codifiable nor readily transferable...Even supposing that [currently existing production techniques] represent optimal solutions for the circumstances in which they are respectively used, it does not follow that they must necessarily be optimal with respect to different circumstances where they have not been previously tested... Once technology is understood in these more complex terms, it is quite obvious that investments in technology are made whenever it is newly applied, regardless of the novelty of the application. Learning about technology and problem solving using the knowledge acquired in mastering technology are not costless, even if the choices made in realizing the technique to be used are identical in generic terms to choices previously made elsewhere... A stream of investments over time is typically required to overcome tacitness and thus achieve mastery. Not only is much technology tacit, so too is much knowledge about the specifics of local circumstances and about the ways that differences in circumstances affect the productivity of particular techniques. Tacit knowledge can only be acquired through investments in learning. (Evenson \& Westphal 1995: 2212-2214, emphasis added)

The following observation expands this notion further. Note the relevant point is that the portion of the firm's capacity to produce in the form of knowledge that is tacit in nature cannot readily be formalised, neither as the blue prints that specify new plant and equipment nor as the matching skills that are needed in the company labour force. This introduces an additional degree of uncertainty into the identification of the skills that will be in future demand. It, therefore, deepens skepticism about skills forecasting beyond descriptions of needs in the most general terms. 
[I]nnovation is defined as the creation of new products and processes, even when these are not at some notional 'technology frontier'. Innovation consists primarily of the accumulation of tacit capability (a process sometimes termed technological accumulation), which capability is embodied in social organization (mainly in firms), and which is to this extent tied to production in a particular location by a specific set of firms (Cantwell 1999: 227).

International trade is a further source of uncertainty about future skills demand that provides a simple and powerful case against fine-tuned skills projections. Given South Africa's recent history of fits-and-starts negotiations with its trading partners, and of bi-lateral concessions by sector, as well as the general move towards liberalisation of economic transactions across frontiers in the past decade, the uncertainty injected into skills projections has arguably become even greater. Being a policy dimension that by its nature is political as well as economic, it is difficult to conceive how any reliable forecasting procedure can take into account changing comparative advantages in foreign trade. In addition, research and discussion in the South African economy about industrial and trade strategy is ongoing. In principle such discussion can be an input into skills forecasting, but there is no evidence of this taking place in government departments, in SETAs, nor indeed in the NSDS as a whole (Edwards 2003).

Further, there is preliminary evidence that skilled unemployment as well as graduate unemployment has risen in South Africa in recent years (Table 6). If true, how is this trend to be reconciled with claims of intermediate and high-level skills shortages amongst the economically active population? The present paper advances no specific answer because no research has addressed this question. But, if significant unemployment at these upper levels has emerged, then it supports a major contention in this paper about the needed micro-level research. At that level where a worker's skills are matched with the requirements of a job, for success a large amount of specific information is required on both sides of a hiring contract. A worker may possess a conventionally defined skill, have the documentation to support that qualification, and yet may be judged unsuitable by a potential employer. Quality deficiencies, including unsuitable personality characteristics, may be the simplest explanation. This is not an unusual circumstance by any means in national labour markets, particularly at higher skill levels. It explains why information about generic occupations is often of such limited use in identifying true labour market supply and demand conditions (Blaug 1985; Spenner 1995). 
Another consideration is that the information technology or 'computer' revolution has not been skill neutral. Rather, it has pushed up the productivity of high-skilled more than it has that of low-skilled workers, relatively speaking. (Feldstein 2003) This is well known and accepted as a trend that is more or less universal. "To provide some examples, computer engineers and programmers have been designing hardware and software that have displaced lower-skilled workers, whether through robots replacing assembly-line factory workers, electronic scanners replacing check-out clerks at retail establishments, or voicemail replacing answering clerks" (Chiswick 2005: 2). Whether the skill bias is temporary, meaning a transitory advantage to those with higher skills because they adapt more readily, or whether it is inherent in the technology and will persist, determines whether the widened payment differential between skill levels is permanent or will decline as the technology becomes familiar to a wider population. This is still unclear, but it certainly makes the forecasting of skill needs additionally hazardous.

In essence what has to be devised for usable projections of skill demands is a system of translation between knowledge of skills needs at an establishment or plant level and a functioning training system. When aggregated, such translation could function at the industry level too. But does the average government have the capacity to run translation systems that have to remain continuously responsive to changing production conditions? Public administrators of such information systems are outside observers who would have to know with reasonable accuracy the real short-term skills needs of the business community and of departments of government at different levels, as well as of parastatals and of non-profit organisations. In fact, to identify labour market needs is to track a moving target with a proportion of skill gaps entirely transitory, opening up and disappearing within the space of months. So it is an open question, best treated sceptically, whether any interest group - employers collectively, the state, or even organised workers - can unaided make human capital projections that are an aid to investment decisions.

Alternatively, it may be more prudent to concentrate on the competencies of economically active individuals within broad groups (by educational qualifications, certificated skills, work experience, age, gender, language proficiency), because these determine the likelihood of labour market success regardless of occupation, sector and specific job vacancies? Much of the new training literature is suffused with cautions about the costs associated with testing the realism of claimed skill needs along with the individual qualifications of every trainee applicant (Culpepper 2001; Blondal et al 2002; Bassanini \& Ok 2004; Bassanini et al 2005; Forth \& Mason 2006). 
Rejection of the main presumptions that underlie skills forecasting is explicit from certain researchers in the field. Couched in the following example in terms of the relationship between education and the skill needs of the economy, this counter-argument applies to all economically significant competencies that are judged necessary by producers.

[T]here is no real sense in which a given level of education in the economically active population in a country can be said to be technically "required" to permit the achieved level of economic growth of that country. Such an argument grossly exaggerates the contribution of manipulative and cognitive skills in the performance of economic functions, ignores the fact that such skills are largely acquired by on-the-job training, and utterly neglects the vital role of suitable personality traits in securing the "invisible handshake" on which production critically depends. In short, educational policies may be fitted to literally any level or rate of economic growth and cannot be justified in terms of those patterns of growth. Education does make a contribution to economic growth, not as an indispensable input into the growth process, but simply as a framework which necessarily accommodates the growth process. (Blaug 1995: 51)

An illuminating example of skills demand forecasting is Woolard, Kneebone \& Lee (2003: 463). This study made the following assumptions about the "macro-environment" of the South African economy:

$\odot$ "The rand is not expected to strengthen in the medium term, implying the continuation of a highly competitive currency and stronger exports (aided by tariff reductions).

$\odot \quad$ Improved government and domestic savings rates are expected.

$\odot$ Low inflation (around 6 per cent), coupled with lower and stable interest rates, is expected.

○ Continued job losses are expected to occur in the formal sector." 
The only assumptions in this set apparently born out by events over the past four years, assuming the forecasting work was conducted in 2001-2, are the two that relate to inflation and job losses in the economy as a whole. Tables 3 and 4 show the anticipated demand for "high-skills" as well as new and replacement demand over the period, 2001-2006, for ten broad categories of occupation.

We do not have independent evidence about the interim growth in demand for these skilled workers with which to test these forecasts satisfactorily. Neither does the forecast model lend itself to simple evaluation of its predicted outcomes based on the derived output-employment elasticities that are used. But, the clear falsification of certain important assumptions concerning trends should make for caution, and indeed for skepticism about the skill projections in these two tables that purport to track incremental demand.

There are at least two types of changes, quite different, which contribute to alteration in the demand for skilled labour: "(a) Changes in the composition of jobs in the economy, and (b) changes in the skill requirements of individual occupations [or jobs]" (Rumberger 1995: 219). Successful forecasting would have to take explicit account of trends in both of these components. There is no evidence in the wider literature on skills projections that these have been successfully tackled in realistic models of output-skill relationships. 
Table 3: Additional Occupational Demand for Specific High-Skill Occupations, 2001-2006

\begin{tabular}{|l|l|l|l|}
\hline $\begin{array}{l}\text { High-Skill } \\
\text { Occupations }\end{array}$ & Number in 2001 & $\begin{array}{l}\text { Percentage Average } \\
\text { Annual Change in } \\
\text { Number of Positions, } \\
\mathbf{2 0 0 1 - 2 0 0 6}\end{array}$ & $\begin{array}{l}\text { Total New Positions } \\
\text { Arising, 2001-2006 }\end{array}$ \\
\hline Academics & 37327 & 0.5 & 914 \\
\hline Doctors & 34370 & 1.2 & 2191 \\
\hline Nurses & 155516 & 1.2 & 9934 \\
\hline $\begin{array}{l}\text { Computer-Related } \\
\text { Professionals }\end{array}$ & 75841 & 2.5 & 9990 \\
\hline Scientists & 4647 & 1.6 & 388 \\
\hline Science Technologists & 4729 & 0.5 & 126 \\
\hline Educators & 354469 & 1.4 & 26417 \\
\hline Engineers & 29824 & 0.8 & 2985 \\
\hline $\begin{array}{l}\text { Engineering } \\
\text { Technologists }\end{array}$ & 32132 & 1.4 & 132 \\
\hline Managers & 280298 & 2.1 & 298 \\
\hline
\end{tabular}

Source: Woolard, Kneebone \& Lee (2003: 469) 
Table 4: Number of People Needed to Meet New and Replacement Demand, 2001-2006

\begin{tabular}{|l|l|l|}
\hline $\begin{array}{l}\text { High Skill } \\
\text { Occupations }\end{array}$ & Number in 2001 & $\begin{array}{l}\text { Number of Workers Required to Meet } \\
\text { New and Replacement Demand over Five } \\
\text { Years }\end{array}$ \\
\hline Academics & 37327 & 6651 \\
\hline Doctors & 34370 & 5207 \\
\hline Nurses & 155516 & 35461 \\
\hline $\begin{array}{l}\text { Computer-Related } \\
\text { Professionals }\end{array}$ & 75841 & 15600 \\
\hline Scientists & 4647 & 795 \\
\hline Science Technologists & 4729 & 599 \\
\hline Educators & 354469 & 73077 \\
\hline Engineers & 29824 & 5116 \\
\hline Engineering & 32132 & 5937 \\
\hline Technologists & 280298 & 45130 \\
\hline Managers & 82003.998 & \\
\hline
\end{tabular}

Source: Woolard, Kneebone \& Lee (2003: 469)

In summary, our contentions under Skills Forecasting are the following:

$\odot$ First, projecting investments in the training of newly skilled workers in sectoral and national occupational markets in an economy is subject to unknown but probably significant margins of error that increase with the time horizon.

$\odot$ Second, there is no firm evidence that in the context of the National Skills Development Strategy, firms in a sector organised by a SETA make use of the sector-wide skills plans contracted by the SETA to inform and facilitate their own investment planning for skills training. This question remains open and it is especially important. 
$\odot$ Third, constructing a Sector Skills Plan (SSP) requires considerable effort and resource input from a SETA, so much so that in the past this periodic commitment to the Department of Labour was carried out for a proportion of SETAs by subcontracted consultants.

$\odot$ Fourth, a number of international studies have pointed out the distorting tendency to use figures of the most strongly growing job kinds as indicating job growth in the economy as a whole (Rumberger 1995). This exaggerates the changes in training requirements, especially where the fastest growing jobs require higher than average bases in formal education in addition to incremental training.

$\odot$ Finally, there is the temptation to concentrate inordinate forecasting attention on the potential growth in demand for filling new kinds of jobs to the neglect of replacement demand, which often is considerably larger in absolute numbers.

A strong recommendation of this paper is that a thorough cost-benefit investigation be conducted into the periodic production of SSPs. This should devote close attention to the role they may or may not play in facilitating higher levels of net skill investment. Do they, thereby, fulfill the purpose of skill projections stated in the NSDS documentation, which is to raise the average level of workforce skills in the relevant sector?

Education and training as policy vehicles are limited in many ways - for example, in the lag between schooling and greater productivity, the loose linkage between skills of workers and skill demands of jobs, and the uneven and uncertain responses of managers and firms to uncertainty. Arguments for increased education hinge primarily on bringing all of the population to minimal levels of literacy and additional schooling for the less well-educated because education and training appear to minimize the adverse consequences of technological change for workers, and workers with such training and education adapt to change better and quicker...Curriculum planning in the face of uncertainty should rely on curriculum diversification and periodic 
review aimed at adjusting available programs to demand. Thus, within modest limits, the research on technological change and skill requirements informs education and training policy, and within modest limits, education and training can be expected to inform and solve human problems associated with technological change. (Spenner 1995: 128-9, emphasis added) 


\section{Theoretical Developments in the Economics of Skills Training}

Any national system of labour-force training must confront and solve a range of problems. Who is to pay for the training; how is training to be organised and delivered; how is the content of training to be established; how is the skill level of a trained worker to be assessed and certified in a way acceptable to all the contracting parties; and how is success in skill acquisition best measured? (Oulton \& Steedman 1994; Archer 2003; Kraak 2005; Heckman 2005) This section of the paper is concerned with these questions as they appear in current literature. Yet to present the policy issues fully, other dimensions of the training problem will be addressed where judged to be relevant. Further, the concern is with high-level and professional skills as well as middle-level competencies, being those above routine skills lower down the hierarchy. These are routine because they are generally acquired by performing a set of tasks over a period of time with little deliberate instruction on- or off-the-job and are seldom certified. Although important in certain sectors these routine competencies are not formally acquired and thus are not discussed here.

Concerning the middle-level or intermediate category, these skills are heterogeneous in content as well as imprecise in their boundaries. Thus, there is a greater likelihood (than with higher skills backed by documents) of ambiguities or arbitrary decisions in practice where particular skills have to be identified and monitored for the purpose of accreditation and for wage bargaining. In the South African case this is where our greatest training deficiencies are said to lie, but discussion of identification and implementation issues is postponed to the next section of the paper (Ryan 1991; Lindley 1991; Booth \& Snower 1996; Wolf 2002; Greenhalgh 2002).

The answer to the first question, who pays, is in principle not complicated. The analytical framework for much subsequent discussion of enterprise-based or on-the-job training was laid down by Becker thirty years ago (1964). He postulated a competitive occupational labour market as a baseline. In accordance with mainstream economic thinking, the common belief is that in such markets employers and trainee workers share the costs and the benefits from training, depending on the portability of the worker's acquired skills between firms and industries. Becker teased out the implications of this model. $\mathrm{He}$ pointed out that where workers who undergo training reap the exclusive benefit that stems from their subsequent higher productivity, then competitive forces in the labour market - 
strictly speaking the relevant skilled labour segment of the market - will ensure that they themselves bear the cost.

Strictly speaking this inference from the model applies only to general or portable skills with multiple uses in different producing organisations engaged in the labour market. These are profit-seeking firms, government, non-profits, NGOs and others. In contrast, employer-specific skills have value in one organisation or line of work, in the limit only within the training enterprise itself. Thus, such company-specific and industry-specific skills have much more limited portability. It follows that in this model the quantity of specific skills available on the supply side will respond markedly less to market forces. Examples of such firm-specific skills discussed in the literature are familiarity with employers' production processes, product lines, market strategies, other employees, and business or organisational culture (Wolf 2002; Jacobson et al 2005: 48).

This distinction teased out by Becker remains a cornerstone of skills training discussion, even though the identification of general in contrast to specific skills can prove to be ambiguous in practice. Note also that "general" does not mean simple. Piloting an airliner or performing heart surgery are general skills because they are highly portable between employing organisations, but, they are specialised in function and amongst the most expensive human capital competencies to be acquired by an individual.

It follows that in a market with sufficient competition in the buying of skilled labour no company will be prepared to invest in training its employees to the extent that the skills they acquire are marketable. That is, this constraint applies to skills that are general in the sense already distinguished, that is, of being productively useful to a range of employers. This is so because after completion of training the newly skilled workers have to be paid the wage going in the market. Where this is the case it could be cheaper for a representative firm to buy-in skills from that occupational segment of the market without incurring the costs of training. Alternatively, if the company attempts to pay these workers less than warranted by their new higher level of productivity on the market, in order thereby to recoup the cost of its training investment outlay, the trained workers will tend to quit and seek the going rate of higher pay elsewhere.

Thus in a competitive equilibrium situation (given the other conditions necessary to assume, like full information) both parties, being the employer and the worker, will invest in training up to the most efficient level. Formally stated, this is where the present value of anticipated marginal benefits equals the marginal costs of further investment of resources 
in skill acquisition. It follows that where this does not hold, where there is inequality between the marginal values of these variables - because of market or state failures suboptimal amounts of investment in skills training will take place. The ultimate conclusion is that either workers or employers, or most likely both, will be frustrated from maximising their desired well-being through investing in skills training.

In summary, the implications of this competitive model are the following.

i) Firms will be reluctant to invest resources in training employees if, once skilled, such workers are free to move to other employers in the industry and elsewhere in the economy to realize for themselves the higher earnings (or rents) from the newly acquired skills. This is the case with general skills, as defined above.

ii) The untrained individual has to finance completely the acquisition of such general or portable skills, either paying costs directly from own resources accumulated or borrowed, or through reduced cash wages and lower fringe benefits to repay training payments made by the employer on the worker's behalf.

iii) By contrast, the cost of investment in firm-specific skills will be shared between employer and worker to the extent that the resulting productivity gains are divided between higher wages for the skilled worker and higher company profits earned per worker. This division will depend on relative bargaining power, trade union activism, state intervention and other variables like the age of the worker and, thus, the length of the pay-off period.

iv) Equilibrium, in the sense of no further impetus existing for workers or employers to invest or disinvest in skills production, occurs when the wage paid to the marginal skilled worker equals the addition to output in value terms from employing that worker; that is, the marginal product in economic terminology. Individuals in the market for skills are satisfied that they are maximising their utility levels because the amount of training taking place is efficient. No-one can be made better off by extra training without some-one else in the work force being made worse off by going without the resources that went into that extra training. This is the standard expression of a Pareto optimal outcome which reflects the opportunity costs of every allocation decision. 
v) Whereas out of equilibrium, if MP $>$ W then additional skills investment by the employer will take place. But if $\mathrm{MP}<\mathrm{W}$ then the marginal skilled worker will be laid off as costing more than his or her contribution to revenue, and therefore generating a net loss to the employer.

The logic of this make or buy decision problem for both the worker and the employing organisation cannot be faulted within the prototype model of a competitive market for labour skills. That model is able to show unambiguously that the degree of market competition for a particular skill determines whether training is in actuality general, specific or somewhere in-between. So the competitive model's conceptual apparatus functions as a baseline, in that it draws attention to the range of determinants that are likely in practice to influence the volume of investment in human capital. It holds under a set of hypothetical conditions spelled out explicitly by Becker.

Yet the difficult questions concern the extent to which any concrete situation in the training sphere of a labour market departs from this model. Following on, there is the attendant task of predicting and measuring the consequences that follow. We want to know how sub-optimal in practice - how far from a training equilibrium - would be the resulting levels of skills training; how serious in foregone investment, investment that does not take place, is the inhibition of skill-intensive productive activities in the economy at large; and what is the loss of potential social welfare that would result? Table 5 is a guide to interpreting such questions. 
Table 5: Some Predictions of Human Capital Theory

\begin{tabular}{|c|c|c|c|c|}
\hline $\begin{array}{l}\text { Row } \\
\text { No. }\end{array}$ & Model & Who Pays? & $\begin{array}{l}\text { Divergence between } \\
\text { Wages (w) and Net } \\
\text { Marginal Productivity } \\
\text { (MP) at training firm }\end{array}$ & $\begin{array}{l}\text { Transferability of } \\
\text { Rraining (Skills } \\
\text { Acquired) between } \\
\text { Firms }\end{array}$ \\
\hline 1 & $\begin{array}{l}\text { Perfect competition, } \\
\text { general training }\end{array}$ & Worker & None & Fully Transferable \\
\hline 2 & $\begin{array}{l}\text { As above but with } \\
\text { credit constraints in } \\
\text { that workers cannot } \\
\text { finance their desired } \\
\text { training }\end{array}$ & Sharing & $\begin{array}{l}\mathrm{W}>\mathrm{MP} \text { during training } \\
\text { and } \mathrm{W}<\mathrm{MP} \text { after } \\
\text { training. }\end{array}$ & $\begin{array}{l}\text { Transferable but wage } \\
\text { returns elsewhere } \\
\text { greater than returns at } \\
\text { firm providing training }\end{array}$ \\
\hline 3 & $\begin{array}{l}\text { Perfect competition, } \\
\text { specific training }\end{array}$ & Sharing & $\begin{array}{l}\mathrm{W}>\mathrm{MP} \text { during training } \\
\text { and } \mathrm{W}<\mathrm{MP} \text { after } \\
\text { training. }\end{array}$ & Non-transferable \\
\hline 4 & $\begin{array}{l}\text { Perfect competition, } \\
\text { mix of general and } \\
\text { specific training }\end{array}$ & Sharing & $\begin{array}{l}\mathrm{W}>\mathrm{MP} \text { during training } \\
\text { and } \mathrm{W}<\mathrm{MP} \text { after } \\
\text { training. }\end{array}$ & $\begin{array}{l}\text { Partially transferable; } \\
\text { wage returns } \\
\text { elsewhere less } \\
\text { than returns at firm } \\
\text { providing training }\end{array}$ \\
\hline 5 & $\begin{array}{l}\text { Oligopolistic labor } \\
\text { market, general } \\
\text { training }\end{array}$ & Firm & $\begin{array}{l}\mathrm{W}<\mathrm{MP} \text { during and after } \\
\text { training, implying rents } \\
\text { for the firm }\end{array}$ & $\begin{array}{l}\text { Fully transferable, } \\
\text { wage returns } \\
\text { elsewhere greater } \\
\text { than returns at firm } \\
\text { providing training }\end{array}$ \\
\hline
\end{tabular}

Source: Bassanini \& Others, 2005: 21 
The next step is to ask whether government intervention is necessary to achieve equilibrium? Cost and benefit estimations must be attempted so as to inform this decision. It cannot be assumed that net gains will invariably follow from state efforts to overcome market failure. There are major methodological issues at stake here which, given the policy-orientation of the paper, we are entitled to sidestep.

To recall, the purpose of this sub-section is to identify the sources of market failure identified in the international literature, either as logical possibilities to be tested empirically, or as interventions and practices that have evolved to modify the market's functioning in different national labour markets for a range of reasons. Certain of these reasons for intervention are explicit in the documentation, others are not (Brunello \& De Paola 2004; Bassanini \& Ok 2004; Bassanini et al 2005; Leuven 2005; Pischke 2005). The extent to which these apply in South Africa is a concern throughout this paper although not readily answered.

An important feature to note about the conventional baseline model resting on competitive assumptions is that the loan or capital market too has to be presumed efficient. If the individual worker faced with a high training cost for a general skill resorts to borrowing then he or she must be able to do so without being liquidity-constrained. This means freely able to borrow for training against future higher earnings. Whether in practice such a constraint is quantitatively important in many economies is contentious (Wolf 2002; Carneiro \& Heckman 2003; Heckman \& Masterov 2004). In the South African economy there is little evidence one way or the other on the prevalence of borrowing constraints for intermediate skills training. But it would be surprising if the average trainee could borrow easily from a bank or some other private financial institution.

Historically workers aspiring to be skilled did accept wages below skilled as well as unskilled grades in early training years of relatively low productivity. The evolution of the apprenticeship system evidenced this over centuries. So their investment in skills acquisition was independent of outside sources of finance. Where this institution still exists the same applies to apprenticeships in force today, although they are far fewer in number because of structural changes like the rise of the services sector at the relative expense of manufacturing's weight in GDP (Crouch, Finegold \& Sako 1999; Ryan \& Unwin 2001; Fuller \& Unwin 2003). 
But many, probably most, workers have few assets as security and thus a limited capacity to borrow against future earning potential. This is so particularly if their educational attainments are at or below average, and they are wholly unskilled as well as unemployed. This is generally the case in developing countries, in some industrial economies, and in evolved situations where there is a measure of labour market dualism as in South Africa. In the latter there are large institutional and organisational differences between the formal and informal segments of the labour market and the labour force.

Initiation of training from the worker's side faced a serious financing constraint under the old training system, quite apart from the barriers to skill acquisition erected by apartheid. A key question now for South Africa's NSDS is what proportion of current skills investment is coming from aspiring trainees rather than from employers - probably only a fraction - but this should be investigated specifically under the JIPSA programme. It would measure the scope provided to unskilled workers to initiate their own training under the present strategy. This question is examined further in section [4].

How capital markets are assessed for training investment is the subject of an emerging literature, for example, Stiglitz (1989, 1992; Claessens 2005). For the present purpose we note its emphasis on information and incentive deficiencies as well as institutions which stand in the way of maximising behaviour by financial lenders and aspiring trainees. Therefore, efficient outcomes of the textbook kind are blocked. What this means for the unskilled worker attempting to finance training by a loan repayable out of future higher earnings is the following illustrative listing of the constraints that apply.

1. There are legal limitations on the commitments a worker may enter. Human liberty is independently valued, so the individual's freedom to pledge future income and residual claims in the case of bankruptcy is restricted. Contracts aimed at binding workers to training firms until the investment in skill acquisition is recouped are usually costly to carry out or simply unenforceable through legal procedures.

2. Potential lenders like banks, at the best of times, have difficulty in assessing the risk of default because they have few ways of ensuring accurate revelation of information by contractual partners like worker applicants who are mere acquaintances. In the case of individual borrowers with few physical assets to 
pledge in return for a requested loan there is no offset to this risk problem.

3. Surety or collateral extended by third parties like an individual lender, the state, collective institution or philanthropic organisation may not overcome this market failure efficiently. Concepts from the insurance industry have entered economics to illuminate how information deficiency can frustrate efficient outcomes. Moral hazard arises in a potential transaction between two parties when the one cannot monitor the other's actions that bear on the outcome; for example, the care taken by the insured to prevent fire after the insurance company assumes the risk. Similarly in the case of skills training, the lender does not know what actions are undertaken by the borrower which affect the probability of the lender being re-paid, like the trainee's diligence during the training process, staying power in achieving certification, and in seeking subsequent employment.

4. Adverse selection occurs in a potential transaction when one of the parties does not know certain characteristics of the other which are pertinent to the consequences that follow. Examples are the other individual's honesty, commitment and health status. For self-protection, thus, the lender treats all borrowers as worse risks on average than most of them actually are. This raises the interest rates payable on any loan, which discourages some better risks from transacting, and thereby changes adversely the average quality of the mix of applicants remaining. In effect information deficiency creates a higher mean risk, fewer loans are granted and overall investment in skills is lower and not utility maximising.

In summary, the market failures accepted as making the standard Becker model of general and specific skills acquisition unsuitable for practical application are of more than one kind. Three examples amongst a larger number are the following:

$\odot$ First, an appropriabilty problem can face training firms that have to recoup their investment outlay over the duration of the 
average worker's period of employment. That is, such firms have to maintain a determinate relationship between increased productivity and increased wage payments in order to stay solvent which they may not foresee to be possible.

$\odot$ Second, because there is a link between incentives to train and restrictions on employment termination, employers have to devise ways of retaining newly skilled workers for the period necessary to make the investment profitable. For instance, Japan has the institution of life-time employment, and Germany has powerful employer associations as well as "social plan" agreements with workers' representatives and trade unions on quitting and severance procedures. These are seriously enforced (Fella 2005).

$\odot$ Third, a pervasive imperfection in capital markets due to information asymmetries can inhibit the self-financing of skills investment by individuals. In South Africa an interesting contrast is provided by the relative success of our National Student Loan Fund to finance higher education. As yet, there are no serious suggestions to provide the same kind of state funding for workers aspiring to obtain intermediate skills. Also, some recent American research denies that credit constraints are quantitatively significant in inhibiting higher education and skills training (Cunha, Heckman et al 2005). But this sceptical conclusion, even if correct, may not apply in economies at much lower average levels of per capita income where difficult access to loan finance may be a more binding constraint.

So in general, failures in national labour markets cause the volume of training on offer and acquired by the labour force to be sub-optimal. There is a wide-spread presumption in the literature that such failures are not mere analytical possibilities but are phenomena that exist in all economies, best documented in the OECD countries (Blondal et al 2002; Bassanini \& OK 2004; Bassanini et al 2005). Circumstances that lead in practice to inefficiency in the markets for accumulating skills, however, comprise a disparate set. Thus it would be prudent to anticipate the presence of some of them at least in the South African training arena. With that in mind, the following are the categories of potential 
market failure that need careful investigating to inform the re-design or reform of policy. As will be noted some local research results are applicable but there are not many, and a major theme of this paper is that major research efforts are necessary at the micro-level of decision-taking and probably are best initiated and funded by the state.

\subsection{Risk Aversion}

Training investments are inherently risky because the monetary returns over a lengthy period are highly uncertain at the time the firm and the worker have to decide jointly whether to invest or not. This lack of sufficient certainty for optimal investment levels is caused by a range of factors, like imperfect knowledge of personal abilities; working and biological lifetimes that vary; unpredictable job search costs and the timing of job offers; uncertain returns to general training; and unforsee-able demand and supply trends for specific skills stretching into the future. Overall, the usual ways of spreading investment risk that are open to individuals and companies through diversification and insurance are considerably more limited in the case of human capital acquisition (Ritzen 1991; Murnane \& Levy 1994; Blundell et al 1999; Hopkins 2002; Keep, Mayhew et al 2002).

\subsection{Asymmetric Information}

Expanding the remarks above on information deficiencies that cause failure of market processes, when the parties to a transaction know different aspects of it concerning the probabilities that govern outcomes over time then an efficient solution is elusive. Joint welfare cannot be maximised. A range of examples will illustrate the consequences.

i) Selection of the most appropriate trainees has to overcome incomplete or distorted information about applicants. Workers are strongly motivated to invest resources in their signals aimed at company or institutional selectors so that their self-perceived strengths are given undue weight. 
ii) Inadequate information about training opportunities limits the capacity of workers, particularly new labour force entrants, to obtain training that is appropriate.

iii) In choosing training programmes, firms and workers are faced not only with a lack of information, but also with the tendency of outside providers and consultants to overstate the content and potential returns from their training offerings. In addition, after the training event to establish the value of skills obtained on-the-job becomes an essential task of intervention by an independent third party. It has to be undertaken by an outside, usually public, agency. The reason is that certification has public good characteristics which mean it cannot be bought and sold on a market like private goods. The defining features of a public good are explained below.

iv) So in practice no profit-seeking organisation can be charged with the duty or even permitted to carry out the task of evaluation and accreditation of acquired skills. Only the state can act in the collective interest of all parties in this respect; that is, trainees, employers and consumers. Note that this rationale for intervention by a non-market authority is separate from reasons for state action aimed at meeting the requirements of standardisation and subsidy payments under laid down conditions. These are a further set of state interventions shown to be efficiency improving by the experience in many national labour markets (Booth \& Snower 1996; Blondal et al 2002; Wolf 2002).

v) Where on-the-job training is more cost-effective than training in off-site institutions like industry institutes and FET colleges, as seems generally to be the case in many national labour markets, the monitoring task of public agencies who are usually outside the production and training arena is commensurately more difficult. They have to keep a watchful eye on training activities on the shop floor. This is one example of a class of non-market or "state failures" to which any training system combining state with market activities is subject (Archer 1997; Parsons 1990; Hansen 1991; Lucas 1994; Jeong 1995; Bassanini \& Ok 2004; Bassinini et al 2005; Lynch 2005; Pischke 2005).

vi) One final asymmetry in information availability underlies the difference between training and non-training firms. Trainers in the company know more about the characteristics, specifically the post-training productivity and value, of the skilled worker. In addition, the size of this informational difference is a function of effective certification which governs the transparency of the skill's value in the market (Greenhalgh 2002; Bassanini et al 2005; Pischke 2005). 
It also provides an employer motive for the non-completion of training in general skills so as not to lose the worker. This is a strategic issue that requires thorough investigation under South Africa's second phase NSDS. There is preliminary evidence that workers entering established learnerships are recorded in relatively high numbers by companies and SETAs, but that the proportion who complete and are eventually certified is significantly lower. If true on a large scale this would be a serious deficiency in the existing system. Estimates have been assembled for the April 2003 to March 2004 period. "The evidence shows that the number of individuals completing learnerships is significantly lower [than the number who had entered], ranging from one-tenth to one-fifth of those who were initially registered" (Lundall 2005: 10).

\subsection{Externalities}

How sizeable the external effects or spillovers are that emerge in the process of human capital formation remains an open question. By their nature arising in non-price form, they are not easily estimated. But there are arguments that general training, as also formal education, has economic consequences which not only spill over the bounds of bilateral agreements to share costs and benefits between the trainer and trainee, but the effects can extend to other firms in an industry. They can even arise inter-sectorally where skills are sufficiently multi-purpose in nature to be efficient in a range of production processes for multiple goods and services (Dixit 2002; Wolf 2002; Asplund \& Salverda 2004; Machin \& Stevens 2004).

The essence of an external effect is that although it originates in the actions of one or more economic decision-taker, it is not reflected in the price system, neither in market transactions nor in exchange relationships within organisations, that is, within the internal labour markets of large companies. Individual workers acquire skills and aptitudes which normally raise their productivity and their wages, but they may also generate external collective benefits for others which the transacting parties usually do not consciously seek. This is the source of a market failure that results in sub-optimal levels of training investment because the full return is not a decision variable. If the positive effects were taken into account the volume of training would be higher. 
It is a widely accepted generalisation in the international literature that large firms provide significantly more training than do small ones. This is true also for South Africa (Badroodien 2004; Kraak 2005; South Africa 2005; World Bank 2005). One explanation is that large producing units are better able to internalize the positive spillover effects - increased profitability - that result from raising skill levels in the work force. Thus, they have a stronger incentive to train. Another explanation is the efficiency wage argument. Increased organisational size makes managerial monitoring and supervision of productive effort by workers more difficult, so it can become profitable to pay above-market wage rates which raise the penalty cost of job loss through slacking and shirking. These higher pay rates are matched by investment in training to make such extra costs worthwhile to the employer through generating higher productivity per worker. As a consequence there is increased diligence from the average worker, including higher work intensity, along with a rise in the average skill level to maintain the higher value-added and increased scale of operation. In small firms by contrast the supervision problem is less serious, according to this argument, so wages are lower for the same work performed and the incentive for skills training is proportionately weaker.

An additional form of skill externality lies in the observed correlation between higher mean levels of training and the ready adoption and diffusion of superior technologies within the labour force (Acemoglu 2002; Temple 2002; Maki et al 2005; Lynch 2005; Forth \& Mason 2006). Individual workers with training are better informed about input-output linkages; they assimilate and follow instructions more effectively; and they diagnose problems and take initiatives with existing methods of production more readily. But, above all, they are more innovative in finding and using new technologies. In an intermediate industrial economy like South Africa at present, it is the dissemination of productivelysignificant knowledge from abroad into producing organisations - firms, government departments, state-owned enterprises and the rest - which is a powerful determinant of long-run growth.

Admittedly difficult to research empirically, it is generally accepted that one key determinant of success in technology importation is the availability of trained labour with basic or general skills. Yet a proportion of the associated gains from deploying new technology do not show up in profit and loss calculations by innovating organisations like companies, being a spillover effect outside the price system. So in any given economy, investment in such technology may be sub-optimally low for a variety of reasons to do with a variety of market inefficiencies in final output as well as capital equipment. But in the absence of sufficient skilled workers, investment in technological innovation would be 
even lower. What that supply threshold is in numbers of workers with the needed skills requires properly designed survey efforts to find out. It may be a binding constraint locally, although there is no evidence of it being so in South Africa despite recent concerns with skill shortages. This issue is discussed further below.

\subsection{Rigidities in Pay Scales}

This is a vast subject because in the revival of macroeconomic debate over the past thirty years a great deal of attention has been devoted to "sticky wages" as an obstacle to market-clearing and, thus a cause of undesirable levels of unemployment. Demands for labour whether unskilled or specified by skill level do not match available supplies because the wage mechanism does not adjust. This can be for a whole range of possible reasons, but the result is a level of unemployment judged excessive by policy makers, whether in a developing country labour market like that of South Africa or in an industrial one like Germany or France currently. Wage compression, when earnings rise less than productivity, can be the result of too little competition or of institutional features like collective bargaining or of policy instruments like minimum wage regulation. At the wage paid to an unskilled or semi-skilled worker, this means that investment in skills training beyond some threshold level looks unprofitable to employers, so a sub-optimal amount of training takes place (Acemoglu \& Pischke 1999, Machin \& Stevens 2004; Bassanini \& Ok 2004; Bassanini et al 2005).

This is a complex and contested issue, but as discussed elsewhere in this paper it is a perspective on the skills shortages diagnosed to exist in the South African labour market that requires detailed research without preconceptions. Perhaps only a state agency can undertake it with the resources required. First, a key question is whether the employer who reports a shortage is in fact willing to hire a skilled worker who becomes available at the wage currently ruling in the market for that occupational skill? Second, if skilled workers are imported from abroad more freely in the future their wage levels will probably have to be lower than local pay rates to make this a profitable option for employers. Otherwise some sort of import "parity pricing" might make such workers equally unappealing because of their cost relative to their productivity. In the present state of research this has to be speculation. 
Wages serve a variety of functions other than equilibrating the quantities of labour offered and purchased in the relevant market. For instance, the wages paid can also be (i) a means for employers to provide job insurance to workers; (ii) for sharing between them economic rents earned on some asset or investment, including new technology and acquired skills; and (iii) for raising work intensity and, therefore, the productivity of a unit of labour employed. This is the notion of an efficiency wage explained already. Also noteworthy is the persistence in practice of significant differentials between firms in what they actually pay for performed work that is perceived to be economically equivalent in the relevant respects. This is likely to be caused by information deficiencies that are assumed away in the analysis of competitive markets. "It has long been a commonplace that apparently identical workers employed by different firms in the same street may earn wages differing by 40 per cent or more" (Layard, Nickell \& Jackman 1991: 165). This is a serious anomaly for the competitive model of human capital investment.

It follows that wage rigidity is relevant to training failure on more than one front. First, compressed pay differentials - a goal of organised labour as well as social democratic governments - below a certain critical level are not compatible with the minimal flexibility required to ensure efficient contracting between worker and employer. This shows up in the form of the main constraint, which is that skill acquisition has to be made attractive to both the employer and the worker in anticipation of increased productivity and higher future earnings. So it has to be affordable to the employer who has to keep trainee pay in line with trainee output. What this illustrates is the old conflict between the two desired goals of equity and efficiency. These may be weighted differently by the bargaining partners, but that is again open to investigation.

Related causes of higher risk to skills investment as perceived by employers are the evolution of institutional restraints on their labour recruitment strategies. Examples are employment protection legislation, social security payments (non-wage labour costs), national insurance levies, and sometimes corporatist agreements with trade unions. South Africa has seen a sub-set of these emerge in the decade since the onset of political change.

One cannot judge a priori that excessive wage compression - earnings that rise at a significantly lower rate than productivity - is a cause of sub-optimal skills training in South Africa because it is unattractive to workers. It is one more research question, though, in a long list requiring urgent attention. In fact in the new literature on monopsony power in 
the skills training arena, such compression is viewed as a factor that can on the contrary make training more attractive to the employer because it generates rents per skilled worker that push up profitability (Machin \& Stevens 2004; Bassanini et al 2005; Pischke 2005; Leuven 2005).

Second, employers design compensation systems to attract stable and long tenured workers. This usually involves the payment of wages lower than marginal productivity early in a career with the promise of the reverse later, if performance along with training completion meets laid down standards. The presumption is that self-selection will preclude work-seekers who lack the desired personal characteristics. This is, however, premised on adequate knowledge on both sides of the contract in advance of hiring if the majority of applicants are to be suitable. In the present context, the problem is that this mechanism of contracted delays in ultimate payment that make training investments profitable to the employer cannot be used for this purpose under rigid pay scales.

Third, with increased labour heterogeneity under technological change, and the necessity for decentralisation of decision-making within firms as they grow larger, efficiency wage practices have assumed greater importance. As explained earlier, these are deliberate payment scales above market-clearing levels to ensure high quality worker recruitment, their retention and their satisfactory work effort from employees, where the direct monitoring of performance in production workers is costly or simply infeasible.

If skills are in short supply through past under-investment in training in an industry or sector, these efficiency increments assume even more strategic importance. (1) With the increased scope for selectivity and worker commitment that results from paying a premium, training costs are potentially lower. (2) Due to skilled worker supply constraints the firm cannot freely resort to external occupational markets, but which it can do for unskilled workers. (3) It follows that where wage inflexibilities are entrenched for covered workers, covered by agreements particularly through union pressure, employers can be constrained from paying at efficiency levels. Thus, the volume of training will tend to be lower. This is a suggestion in the international literature (Brunello \& De Paola 2004; Bassinini et al 2005; Leuven 2005; Pischke 2005).

The question outstanding for this paper remains whether South African companies, parastatals and state department employers face similar institutional and regulatory obstacles in wage setting that diminish overall training output? Besides its importance 
for policy formation, wage levels and increases are also political hot potatoes which merit high research priority. It would be naive, however, to anticipate that the recently assembled evidence about the linkages between training and multiple influences like active unions, minimum wages, employment protection contracts, and varieties of product market competition yield a consensus (Wolf 2002; Brunello \& De Paola 2004; Leuven 2005; Bassanini et al 2005).

\subsection{Immobility}

If workers face high moving and job switching costs, in the form of broken family commitments, supports and the search for housing, schools and other amenities, then their set of potential employers, and ipso facto the training opportunities open to them, are likely to be reduced. Conversely, employers are able to exercise greater bargaining or monopsony leverage in local occupational markets, so that particular types of skill command a lower wage where worker movement is constrained. Sub-optimal levels of investment in training are the probable consequence.

With this in mind, certain institutional inheritances of the apartheid era that affect mobility are specific to South Africa. Examples are: the residential layout of cities in relation to its employment sites; the stock and location of educational plant; as well as fragmented lines of authority and responsibility in training provision inherited from the past. In addition, apartheid-based discrimination in such training is probably the best known constraint. All these constitute barriers to mobility. They are therefore independent causes of failure in the market for training, independent of those already identified.

\subsection{Internal Labour Markets}

In an environment in which it is claimed that both domestic and international economies are marked by rising uncertainty in routine investment decisions because of increased global competition, large employers in industrial countries wishing to hire more skilled workers have come to favour use of internal labour markets. This is the deliberate utilisation of company insiders over the recruitment of outsiders as a way of coping with 
higher levels of risk about worker quality. Within the firm, workers subscribe to a set of rules concerning seniority, promotion, pay scales and the in-house criteria applied to selection for skills training (Bassinini \& Ok 2004; Pischke 2005; Forth \& Mason 2006).

To illustrate the argument, a particular driving force for the enhanced role of internal labour markets is the growing importance of firm-specific skills to cope with IT advances. These are investments with long pay-off periods, so to make them profitable there is a motive to tie trained workers to the organisation during cyclical downturns. Seniority arrangements, like pay and perquisite packages according to time-in-the-job, are one such device. A worker separating from an employer early in the job spell faces large financial penalties because of the "end-loading" of life-time earnings, that is, higher pay levels later.

This practice itself has a training function. By reducing internal competition for high status jobs and advancement among individual workers, seniority rules can create an environment in which experienced workers have less reason to fear the loss of their jobs, and so they are more willing to train inexperienced, usually younger, colleagues who would otherwise be their potential replacements. Outsiders - available from external occupational markets - are certainly still hired for contracted periods, but their receipt of enterprise-based training is rare.

From a policy point of view, the social cost of such internalisation practices is that the segmentation of the economy's labour force is deepened. The division is between those who are relatively well-paid on stable career paths with training, and those on fixed-term employments with limited prospects for skill acquisition and advancement. The flexibility and productivity gains that ensue for large companies cannot be discouraged. But they must also be balanced in the public interest by policy attempts to provide opportunities for skill enhancement to the outsiders or secondary labour-force, either in work-places by subsidy or in state-provided facilities.

The finance and delivery of such training, particularly on-the-job-training (OJT), requires much institutional ingenuity in South Africa. Private sector campaigns to relieve skills shortages as well as state programmes like JIPSA are evidence to this effect. The international literature applicable is extremely large and in need of careful sifting and synthesising. Only a start is made in the present paper (Gasskov 1994; ILO 1995; Booth \& Snower 1996; Keep, Mayhew et al 2002; Ananiadou et al 2003, 2004; Bhorat \& Lundall 2004; Black \& Lynch 2004; Cunha \& Heckman 2005). 


\subsection{Labour Standards}

These are state-mandated provisions in employment contracts viewed as advantageous by incumbent workers and usually by the larger employers. Some interventions are intrinsically valuable, like anti-discrimination clauses; and some are instrumentally valuable in aiding the achievement of desirable ends, like health and safety standards, pension rights, due process for disputes and the terms of monetary compensation. In addition, certain provisions aim to be directly redistributive, like sectoral or national minimum wage determinations.

While desirable in themselves for workers who receive them, these interventions can stand in trade-off relationships to other policy goals for larger constituencies. One such goal is the higher level, more dispersed incidence, and deliberately compensatory nature of skills training. In other words, enforcement of certain standards can lower investment in the production of human capital, a perverse outcome.

Trade-offs exist because the application of legalised standards in labour markets with still-evolving institutions, South Africa being one example, can inhibit potentially beneficial exchanges between employers and workers from taking place. For instance, mandated hiring costs can depress the rate of hiring and the creation of wage-paid jobs, while contradictorily encouraging sweatshop production in the informal sector. There is recourse as well by work-seekers to new self-employment. In these fall-back alternatives chosen by workers training seldom takes place.

The possible implications of ambitious standards laid down by policy for the volume of training activity are not difficult to project. If their economy-wide application leads to more hiring reluctance overall, then the number of on-the-job training slots will be lower than might otherwise attract all contracting parties. This is difficult to quantify. That it is also controversial goes without saying, but that is no reason to ignore the distinct possibility of it occurring.

Although it is unfortunate that labour market and social policies that pursue desired goals are not all complementary to each other, any rational process of policy formation to raise investment in skills training must take these into account. Incidentally, the civil protests in France during March 2006, concerning proposed legislation to weaken employment protection for youth entering the labour-force, is because the envisaged change was 
perceived as a reduction in standards. This response is an example of the problems that can accompany reforms to achieve one social goal, higher employment, at the expense of another, security of employment. (Bean 1994; Keep, Mayhew et al 2002; Wolf 2002, 2004; Ananiadou, Jenkins \& Wolf 2004; Lindbeck 2005; Machin 2006; Woessman 2006) 


\section{Training Practices, Institutions and Financing}

One obvious question is why profit-maximising companies in practice do finance part or sometimes all of their workers' general training, when the competitive model predicts that it is a high risk strategy for them? In theory there is no way for them to hold onto the worker once trained in transferable skills and open to job offers from other employers. If so how do employers successfully reap a return on such investments? The pursuit of mutual goals on either side of the training divide - by trainer and trainee - may be hampered, or in this case, may be assisted by the kinds of market failures already discussed? We do not know. A number of answers are suggested in the literature, and a selection is summarised below in numbered paragraphs. Where applicable, we describe the matching institutions that have evolved in a range of countries to support stable training equilibria.

\subsection{Rapid Technological Change}

If the returns to existing skills are declining relatively due to a high rate of technical progress in an industry, so that only firms that keep up with the shifting technological frontier can provide the new training, workers will not readily resign their jobs to search for better ones. Due to uncertainty and risk aversion they may not do so even when paid a wage below the full marginal product of their skills over a period long enough for the investment outlay to be recouped by the employer. Up-dated training to overcome such obsolescence in work competencies then can become worthwhile to the firm wishing to capitalise fully on the new techniques of production available (Pichler 1993; Freeman 2002; Ananiadou et al 2003; Lynch 2005).

\subsection{Remedial Training}

American studies have identified enterprise-based training efforts which are not only general in character but even remedial, being deliberate attempts to overcome schooling deficiencies in the work-force. Seemingly this is profitable in a supply environment that lacks the required skills which otherwise might be bought-in from the market. Informational asymmetry might also be at play, although the evidence is hard to come by. Already 
employed workers, known to be of the high-school dropout standard in the American context, have work-related characteristics known to the employer. They contrast therefore with newly hired workers who possess more of the basic skills in demand but are also more at risk of proving unsuitable in the other dimensions wanted, like sociability, reliability and adequate capacity to learn.

Careful reading of the corporate profiles indicates that an important underlying factor in many firms [engaged in training] is a growing concern about the quality of the products that the firm produces...In sum, the forces behind the emergence of work-place education programs for hourly workers are many. Firms are concerned about both efficiency and quality, and they also recognise that they must somehow fundamentally alter the way in which they go about production. Their customers are in many cases creating the push for this to happen. At the same time, managers recognise that work-place education is good for workers. In these firms, work-place education is clearly viewed as a win-win situation, as opposed to the win-lose situation [in skill acquisition] that is described by the theoretical framework of neoclassical economics. (Bassi 1994: 64-5; Mclntosh \& Vignoles 2001; Keep, Mayhew et al 2002; Ananiadou et al 2003)

\subsection{The Options Value of Training}

The economic value of completed training needs to be conceived as in two parts: its use in the intended employment within the training firm, and its "options value" in the future. Thus, its potential multiple uses in other jobs - its polyvalency - is a basis for further skill acquisition, including for raising the worker's ability to deal with emerging new technologies. It is contended that a non-training firm, considering the poaching of needed skills, has relatively little knowledge of the potential polyvalency. "[So this] informational asymmetry between a training and a recruiting firm therefore reduces the net benefits that a worker with general training can obtain by moving to another firm. We shall argue that this implies that a firm may find it feasible to finance part, or all, of a worker's general training" (Katz \& Ziderman 1990: 1148). 


\subsection{Social Expectations on Training Provision}

Another explanation for employer-provided general training is political economy in nature. It invokes a social expectation about the collective rather than individual responsibility for financing post-school education and training that has evolved alongside the other features of a welfare state in industrial countries. In a sample of British firms studied in 1990 all training was company-funded because (1) in the employer's perception "training outlay [is] an inescapable operating cost, rather than an investment in human capital"; (2) "managers...cited equity. Young people in further or higher education do not contribute to their tuition costs, and may even obtain maintenance grants, depending on parental income. So young people leaving school for the work-force do not see why they should pay for their costs of training" (Hart \& Shipman 1991: 77-8; Keep, Mayhew et al 2002). Clearly this expectation relates to the finance or credit market failure raised earlier, which blocks borrowing by individuals wishing to upgrade their skills but requiring financial support to do so.

\subsection{Externalities and Joint Supply}

Two other explanations of firm investment in skills that are at least partly portable by workers between different employers - contrary once more to the predictions of the text-book human capital theory - must be noted as logical possibilities because we do not know the motives. Such investments may rest on the presumption of increasing the beneficial effects from other kinds of investment, like acquiring new technology and generating company loyalty. Alternatively there is the hypothesis that general and firm-specific skill types comprise an inseparable mixture when produced, a joint supply commodity. This is a sufficient cause of market failure, but difficult to pin down in research (Bassanini et al 2005; Brunello \& De Paola 2005; Pischke 2005).

The most important result of this paper is the simplest: that not all transferable skills are general, and for some types of on-thejob training for transferable skills, firms - both the training firm and external firms - can obtain a positive share of the return to the training investment. This may explain why firms have been found to invest in transferable training. It also means that there is 
an externality - of the type sometimes referred to as a poaching externality - associated with some types of...programmes, which may lead to under-investment in training...It is imperfect competition between employers in the labour market on which the existence of an externality depends: if there is a possibility that the worker will move after training to a firm which can pay him less than his marginal product, that firm obtains a positive share of the expected return to training. (Stevens 1994: 557, emphasis added)

\subsection{Exporting Training Institutions and Substituting Functional Equivalents}

In international comparison of skills production the German and Japanese training systems are widely accepted as the most successful. But the extent to which their component institutions and practices are exportable is a major policy question. In outline the German system is the following, although it should be noted that only a minor proportion of the full cost of the dual system, 10-15 per cent, is contributed by "public money" which means from state revenue sources at one or other level (Drake 1991: 216).

Germany's tripartite structure of employers, unions, and the government jointly determines a national strategy for training; this arrangement also appears to have solved the problem [for firms] of capturing returns to training. Local chambers of commerce use moral suasion to protect firms training a large number of workers from excessive poaching. More generally, the German dual system of apprenticeship training is characterized by co-investment in training by workers and firms, by codetermination of training program content by unions, employer associations, and the government, and by nationally recognized certification of skills on completion of training. As a result of these three components, German firms undertake a great deal of general skill training, and this generates a high-skill, high productivity equilibrium (Lynch 1994: 4, emphasis added). 
What such explanations of enterprise-based training show is that, to overcome market failures, practices have evolved in industrial countries which are compatible with utilitymaximisation by workers and profit-maximisation by firms. Yet the most pertinent feature from a policy reform perspective is the kinds of institutions that foster such efforts by at least the large companies in an economy. For instance, most accounts of the German and Japanese systems describe the evolution of practices and policies which maintain high-skill equilibria in the training sphere. These include powerful employers' associations in Germany, the economy-wide certification of skills, and the low apprenticeship wages paid. These are low relative to skilled rates in the domestic labour market and to the parallel pay differentials existing in other countries. In the Japanese case, the relevant institutions are long-term employment commitment and pay flexibility, some of it linked to the extensive sub-contracting of production.

The problem already mentioned is that institutional practices are not easily transferred between national economies, as evidenced by the earlier South Korean failure to replicate successful German practice (Jeong 1995; Green et al 1999; Wolf 2002). For the present purpose, to provide perspective on South African policy formation, it will be of considerable use to identify not only the institutions but also the functions they perform in the training spheres of other countries. With an eye to local application, this must allow for the substitution of functional equivalents should the practice or institution in question be so embedded in its particular cultural context that it cannot be duplicated in detail in our local labour and financial markets. This is not a question to which there is an easy answer. In particular, whether the SETAs are an effective substitute for parallel institutions in other national labour markets (like industry employer associations) is the main test of their efficacy. To date no clear results from research work are at hand.

ne further constraint on institutional substitution unlikely to be contested is the performance of the national educational system. Not only are the numbers, levels of achievement and quality amongst school graduates all key determinants of profitability in subsequent training investment, but equally pupil motivation can be spurred by recruitment prospects for jobs which include a commitment to training known to school-leavers. This is accepted to be the case in a range of countries like Japan (Rychen \& Sagalnik 2003; Arulampalam, Booth \& Bryan 2003; Machin \& Stevens 2004; Heckman 2005; Cunha, Heckman et al 2005). 


\subsection{Constraining the Turnover of Skilled Labour}

The raising of job security or, what amounts to the same in effect, the lowering of worker turnover to protect the value of investing in portable skills is from the employer's perspective a necessity for a stable training equilibrium to emerge. While this can occur simply as a post-training consequence of increased employee loyalty in some national contexts, contrary to the predictions of the competitive model of voluntary training in the labour market, public policy may be able to encourage or even initiate change in the direction of security. (Bassi 1994; Leuwen 2005; Pischke 2005; Bassanini et al 2005)

A number of institutions and practices are suggested by the available literature, although not all are equally amenable to direct intervention by a state agency. These include:

$\odot$ targeted subsidies for current employees in danger of losing jobs because of recession, or from the structural decline of an industry, or through technological change (Stern \& Benson 1991; Keep, Mayhew et al 2002);

$\odot$ tenure-related wage scales, as in Japan, so that quitters face the loss of high future gains through job-switching if that occurs too soon after training completion (Hashimoto 1991, 1994; Booth \& Snower 1996; Wolf 2002);

$\odot$ moral suasion exerted through chambers of industry and commerce to protect training firms from excessive skills poaching by others, as in Germany (Soskice 1994; Lynch 1994; Culpepper 2001; Greenhalgh 2002; Wolf 2002); and

$\odot$ the enforcement of contracts entered into by employers and trainees that prohibit the worker with skills acquired in the company from joining a competitor during a specified period. This provision echoes that in apprenticeship agreements in earlier centuries where the apprentice's right to compete with the instructing master after completion of training was expressly limited (Parsons 1990; Lalonde 1995; Keep, Mayhew et al 2002). 


\subsection{Risk Pooling and Insurance Possibilities}

A positive payoff to training investment can be realized through insurance schemes or collective funds of one or other kind, although these are proposals more often than actual practices in industrial countries. Two examples are (1) a revolving training fund that combines subsidies paid but balanced by taxes levied on newly-skilled workers; and (2) guaranteed minimum post-training wage levels where supplements are paid to those earning below the minimum but financed out of taxes collected from those earning above it. In theory, the outside-the-market contribution to the policy instruments in both proposals (1) and (2) is organisational not financial in kind. If successful no net subsidy is entailed, or at least no large resource input into the scheme has to be made by the state, by industry or by a collective training body.

The principle is familiar and clear. Pooling risks and providing assurance that beforethe-fact commitments will be met even when conditions change overcomes the inhibiting effect on training investment of the potential for time inconsistency. This problem arises when one party to a contract aborts the agreement once new information on the likelihood of outcomes becomes available. The state can be such a party. So, put in economic terms these strategies work only when there are no hold-up problems. Normally such solutions require special institutional arrangements that may or may not evolve without the intervention by an agency outside the market. But should the state take on the role of ultimate guarantor in skills investments there are clear dangers of increasingly risky behaviour leading to social losses, as is outlined under subheading 4.13 below (Ritzen 1991; Feuer \& Others 1991; Drake 1991; Dixit 2002; Leuven 2005).

\subsection{Skills Certification}

An independent institution for accreditation is essential. Strong arguments can be mounted for its initiation and implementation by the state rather than industry certification by a professional or collective body elected by firms and workers.

First, acquired skills are made portable through being defined, designated, accepted and therefore traded uniformly by all participants in occupational labour markets. In the absence of such standardisation, the productive significance of certain skills is not 
recognised, causing pricing anomalies to emerge. The law of one price does not hold, in that the same work tasks are performed at different pay rates. In consequence, the exchange of skills and investment in their production is inefficient.

Secondly, the certification of any supplied product, including acquired skills, is itself a peculiar commodity. Certification has definite public good characteristics, described under the next sub-heading and summarised in Box 1. Certification is a piece of knowledge which cannot be bought and sold in the normal way, in that it is seldom in the interest of individual transactors - in the case of skills, trainee worker or employer or both - on their own to bear the costs of certification. Rather they are induced to free ride. The costs inherent in certification include the collection of information about the content and other relevant characteristics of the training course; assessing the acceptability of such content and of the testing procedures; issuing documents with legal force; periodic monitoring of practice; and maintaining appeal procedures. These are familiar pre-conditions applying to national examinations in education.

Thirdly, it is essential that certification means that certain minimum standards of performance are met in the public interest. As already observed about the general problems of information asymmetry in the training arena, this points to state responsibility more than to private or professional testing bodies operating under licence. One illustration is Japan, where it is clearly recognised "that it is the customers, whom for the most part only the state can represent, who have an interest in making sure that plumbers can actually plumb and engineers engineer" (Sako \& Dore 1988: 79; Wolf 2002)

The implementation problems inherent here should be noted. Externally-determined standards tend to adjust only slowly to changing work practices, usually because skill monitors and trainers operating outside firms or other production organisations have difficulty keeping up with the evolution of new technology and work organisation (Temple 2002; Black \& Lynch 2004). A further complication is the fact that individual employers have an inherent interest in developing and certifying skills on a basis that accords with their own needs, resources and inclinations, but which are often too narrow and firm specific for successful market trading of the skilled worker's services. (Leuven 2005)

However, the most serious difficulties attach to the carrying out of monitoring itself. If enterprise-based training or OJT is frequently more effective than what is institutionally supplied by a training institute or college, as attested by German, Japanese and other 
national practices in major economic sectors, then there are serious informational and organisational barriers facing accreditation bodies (Ryan 2001; Lynch 2005). Such authorities are external to the site of production, heavily the domain of the private sector, but charged with continually assessing the content and standard of skills acquisition during economic activity. Locally, these are constraints inherent in the work of the skills bodies at sectoral and national levels like SAQA is charged with making the National Qualifications Framework inclusive of all economically significant skills in South Africa. The potential problems are discussed further below.

\section{Box 1}

\section{Knowledge as a Privately Produced Public Good}

Recent research on the economic properties of knowledge may lead to important policy implications. The 'public good' nature of knowledge is well-established - in other words, unlike private services which imply exclusion or rivalry [between consumers or users], access to knowledge can be given to all. The policy implication is clear: market forces in and of their own are likely to lead to underprovision of knowledge. This would justify government intervention in this area to ensure an adequate provision of the public good.

Much less explored is the fact that knowledge is a special public good, in that it is produced by individuals (i.e. it is a privately-produced public good). In this case, distributional issues become essential: knowledge opportunities have to be distributed [amongst individuals] in a way which ensures efficiency. Indeed, unlike the case of typical public goods, distribution cannot be separated from efficiency considerations in the case of knowledge. This reinforces the importance of improving access to quality education and access to new technologies for all.

Source: Arnal, Ok \& Torres (2001: 38) 


\subsection{The Public Good Dimension of Training}

Where a commodity has certain characteristics which inhibit or obstruct its free exchange in a market, then it is deemed either a public good or a mixed good with public and private dimensions. The defining features of such goods are that they are non-rival, meaning that more for one consumer does not mean less for another. They are also non-exclusive in that no-one wanting to consume can be stopped from doing so if they do not pay or fail to meet other criteria of rationing or access. Where and wherever these characteristics apply there is the potential for free-riding. Purchasers - consumers or producers if the commodity in demand is an input like skilled labour - are under no compulsion to pay the full resource cost for acquiring it. Clearly market allocation then fails.

Insofar as training involves the transmission of conceptual skills, meaning abstract, problem-solving abilities, there is a case for treating it as at least partially public good in nature. Recouping the costs of producing such skills - an absolute requirement for all private goods - is notoriously difficult for public goods as demonstrated earlier. The poaching of skilled workers by non-training firms, and therefore the inhibition or undersupply of that skill in the economy, lowers social welfare because it leads to suboptimal levels of investment in their acquisition. Overcoming this public good dimension of training by encouraging or regulating co-ordination between the contracting parties, is the challenge to all institutional innovations in national labour markets. Aiming to obtain a "high-skill" rather than "low-skill" equilibrium along German or Japanese lines, or indeed to copy other national success stories that use training collectives by design like France and Australia, is what reform efforts attempt to do (Finegold \& Sokice 1988; Parsons 1990; Ashton, Maguire \& Sung 1991; Soskice 1994; Heckman 1994; Dixit 2002; Black \& Lynch 2005).

\subsection{Skills as Complements to Research and Development Investment}

How to internalise the external effects of skill acquisition arises as a policy question to the extent that a trained worker's value as an input in production is not accurately reflected in the price system. Therefore the volume of training is lower than it might be, because the return to investment in the decision-taker's perception is partial not complete. One particular argument is that skilled labour of various kinds is a complement to research 
and development (R\&D). Like all forms of knowledge, it generates positive spillovers when all necessary complementary inputs are present. Other firms can benefit from R\&D investment by one of their competitors in an industry. This occurs in two stages. First, it arises directly from the new technology that is deployed in their common industry because information about it is imperfectly excludable, i.e., it spreads between firms. Secondly, its use in production by one firm can raise productivity in others eventually because of a learning-by-doing process. This refers to success in extracting more of its output potential as it is assimilated over time by other producers, with a consequent rise in industry-wide productivity. The institutional and intervention issues relevant to policy formation here are made more complex by all of them lying at the confluence of numerous policy arenas, like labour, industrial policy, foreign trade, education, and R\&D but particularly applied research.

[There is] a strong positive correlation between a country's productivity and the import-weighted R\&D of its trading partners. This impact is greater the more open the countries are, the more skilled is their labour force, and in the case of developing countries, the more trade there is with developed countries...But openness is not sufficient - there needs to be absorptive capacity and ability to adapt foreign technology, both of which are related to humancapital endowments and investment in R\&D-intensive industries. (Hoekman \& Javorcik 2004: 460, emphasis added; Wolf 2004)

\subsection{Collective Decision-Taking Bodies}

Monitoring the delivery and content of training calls for bodies or boards on which skills investors like firms, workers, purchasers of skills and the state are represented, either with equal weight or by a collective agreement about membership proportions. Certain informational difficulties were raised above under the heading of accreditation, where all parties need to play a contributory role. But in addition there are issues of collaboration and legitimacy to be solved. For instance, the acceptability of low pay to new entrants seeking training, as well as workers embarking on retraining, requires that organised labour should support such agreements. Quid pro quos available to trade unions, for instance, are the provision of guarantees on the quality of training and of prohibitions 
on the substitution of existing workers by trainees. The latter is argued to be always a temptation to employers. British experiments in recent years, for instance, the Youth Training Scheme and its successors, have been plagued by problems under this head. In South Africa there is no evidence bearing on these issues yet (Marsden \& Ryan 1991; Keep 1991; Hart \& Shipman 1991; Ryan 2001; Wolf 2002, 2004; Badroodien 2005; Kraak 2005).

\subsection{State Loan Guarantees and their Hazards}

To offset successfully the informational lopsidedness that blocks efficient transacting between companies, aspiring skilled workers as well as training providers, is to overcome the problems discussed earlier as moral hazard and adverse selection. They concern the devising of appropriate incentives, enforceable contracts and countering of opportunistic behaviour by one or more economic agent (Dixit 2002).

One example is the potential for market failure attaching to loans made available to trainees and training providers through a policy of intervention. For reasons outlined in the previous section, private lenders in financial markets like banks are reluctant to enter this line of business because of the high probability of default. They cannot distinguish good risks from bad risks and there are few sources of surety available for the acquisition of intermediate skills.

Unfortunately, what appears to be the obvious solution, which is for the state to act as final guarantor of such training loans, is itself hazardous. Private banks because they cannot lose - ultimately they are insured by the state's guarantees - will be induced to enter transactions that on balance are too risky by their normal criteria. Not only is there the strong likelihood that a high proportion of trained individuals will not repay loans, some because they are unemployed, but also because some individuals in work may resign in order to enter training programmes once the probability of personal loss has been lessened by the loan guarantee. The net result is that taxpayers bear the cost. Judged by efficiency standards, resources expended in meeting such last resort guarantees may have alternative uses with greater social efficiency if the likelihood of changed behaviour raising the risk to state guarantees had been taken into account before the allocation decision. 
This section of the paper has described a sample of training practises and institutions discussed in the international literature. Some evolved within the market and others resulted from state intervention. In view of the obstacles that face the transfer between different national labour markets and their training arenas of such procedures that proved successful, it makes sense to concentrate on the functions performed by interventions in overcoming specific market failures in skills production. These warrant investigation and active encouragement, without passing premature judgement on their efficacy or feasibility. Nor of course is it justified to presume that their benefits will outweigh their costs in all cases. Such a tactic should assist the search for parallel or substitute mechanisms in South Africa. But pitfalls are indeed possible and the most likely ones are outlined in the next section. 


\section{Potential Problems in South African Application}

To recall one impetus for this paper, it is to concentrate policy attention on one of two major labour problems in our economy, a deficiency in basic skills, the other problem being the high level and persistence of unemployment. The origins of this first deficiency regarding skills lie both in our particular economic history and in developments in the wider international environment. On this view, the determinants of this shortfall in skilled workers include our schooling system, the peculiar occupational market institutions of our apartheid past which divided the work force in ways antithetical to skill acquisition, and the economy's structural evolution towards, first, the greater weight of manufacturing and then, second, towards services in the later make-up of Gross Domestic Product (GDP). Most recently trade liberalisation, ignoring its other consequences, has raised the pace of technical changes imported from abroad, a process that at the same time raises demand pressure for both intermediate and higher-level skills.

It is prudent to argue that no one national model of training borrowed from elsewhere is likely to fit our needs. This is so for a number of reasons but two are particularly pertinent. First, it is not possible to identify a single best mechanism to organize and finance training. All countries contain mixtures of market and state financing, and mixtures of organisational responsibility, along a wide spectrum. A variety of classificatory schemes is suggested in the literature; for examples see Tables 1 and 2. Yet the important dimensions can be reduced to the following two:

$\odot$ The signalling function is either performed predominantly by the market for training, or it is supplemented by an information system aimed at matching resources to skill needs through sectoral or state agencies using planning projections of one or other kind. An earlier section of this paper argued for scepticism about the operational use of sectoral and national skills plans.

$\odot$ The financing mode can be direct spending from the revenue flows of enterprises, trainees and private sponsors. Such investment flows are then constrained by horizontal market relationships subject to some varying degree of competition. Or payment can be instituted out of tax revenues or facilitated by public borrowing guarantees, and be subject to top-down 
interventions by one or more layers of governmental authority (Drake 1991; Lynch 1994; Booth \& Snower 1996; Badroodien 2003; Kraak 2005).

A second reason why no single model from elsewhere will suit South Africa is because institutions can seldom if ever be transferred on a one-to-one basis between countries. They require complementary supports that also differ. For example, employer organisations in the shape of strong formal and informal ties between firms at the industry level are a necessary condition for co-operative training. But, they are by no means a sufficient condition. In the prominent German case, co-operative industrial relations and a financial system that fosters long-term company decision-making about human resource investment have proved to be integral elements (Soskice 1993, 1994; Lynch 1994; Heckman 1994; Keep, Mayhew et al 2002; Pischke 2005).

One salutory example of unsuccessful international borrowing already mentioned is the Korean attempt since the early 1970s to reproduce features of the German dual system. These characteristics are notably its close co-operation between training firms and vocational institutions, and the production of an intermediate managerial group along the lines of Meister craftsmen. Neither of these have been achieved with enough success in the copied system, mainly because the complementary mechanisms and institutions were not present in Korea. The system there is the "market replacing" type where the formulation and implementation of vocational training policy remains dominated by state bodies (Drake 1991; Jeong 1995).

It will be helpful to cull from the literature a list of issues that involve hard choices and the dangers of potential failure - or even of perverse results - in the ongoing modification of South Africa's training regime. Our national concern is with intermediate or middle-level skills gaps and shortages along with certain categories of high-level skills. 


\subsection{Situated Learning and Training}

For years to come the overwhelming majority of our trainees acquiring market-ready competencies will lack basic skills. This is because of deficiencies in their compulsory and further education, principally in mathematics, science and communication abilities. These foreclose many opportunities for employment. A dozen years ago amongst "registered unemployed persons" in 1994, 77 per cent had not completed Standard 10 (Grade 12) and 35 per cent not Standard 6 (Grade 8) (South Africa Department of Labour 1995: 80). More recent data reinforce rather than offset this gloomy picture. So these percentages indicate that a significant proportion of our future training will be remedial in nature even if it is not identified as such in the work place (Archer 2003; Bhorat \& Lundall 2004; Department of Labour 2005; Oosthuizen 2005; World Bank 2005).

In the international literature the applicable terminology concerns basic skills - by convention reading, writing, numeracy, and recently computer competency - that are lacking in labour force entrants who did not complete secondary education, or in high school graduates not qualified adequately to move on to vocational or tertiary education. One reasonably typical expression of national concern is by Lynch (2005: 3) describing the ongoing problem in the United States.

[We] are now producing a greater share of low-skilled youth than we did thirty years ago. Thirty years ago $25 \%$ of 17 year olds dropped out of high school and did not return or only did a GED. That percentage today has risen to $28 \%$. Meanwhile around the world, young people are staying in school longer and outperforming US youths with respect to math and science...A simple picture can help put this into perspective. The following figure [not reproduced] shows by country the share of 16-24 year olds who had difficulty adding up two numbers on a bank deposit slip. One in four young people in the US cannot perform this simple operation versus less than $5 \%$ in countries such as Germany and Sweden.

Concern about basic skills deficiencies applies also to a proportion of mature workers in a range of countries with often even lower levels of formal education, some in wage employment, some self-employed and some unemployed. However, the rates-of-return to training investment in older workers in industrial countries when these have been 
calculated, as in the US and UK, tend to be minimal or negative (Heckman 1994; Cunha, Heckman et al 2005; Wolf 2005). This shows up a stark conflict between efficiency and equity goals in national resource allocation to skills training, because investing in skills acquisition by older workers may simply not pay. Although for us in South Africa this is probably true here too, the main lesson on a wider canvas is that it highlights the complexity of devising a system that has to serve our multiple constituencies both efficiently and equitably.

Two related observations need consideration. First, at the economy-wide level of allocative decisions on human capital, spending on basic skills training, spending to raise quality in formal education at every level, and spending to provide second chance or remedial programmes in schools are all substitutes. They compete for resources in that every such expenditure aims to achieve a similar end, which is to raise the work readiness, productivity and earning capacity of labour market entrants. Secondly, the choice between them must hinge on the relative rates of return in these different avenues of investment, insofar as these are even roughly calculable.

A major deficiency of current skills policy discussion in South Africa is that these trade-offs tend not to be recognised. In part the problem may be the result of multiple institutions existing. Responsibilities in education and training are shared between at least three national government ministeries, as well as numerous agencies set up by government and reporting to one or more of these departments. Whether there are international precedents on successful collaboration which our training endeavours can learn from during the conduct of the JIPSA programme is still an open question that must be addressed.

These observations are not analytically controversial, although estimating relative rates of return to inform decisions about the ranking of investment projects may not be practical in the absence of much more intensive research efforts. What is additionally pertinent to raise as aquestion is what is the most effective means of skills delivery? Is it likely to be off-the-job or on-the-job, in schools, FET institutions or in work-places? Tentative international evidence points to "situated learning" or on-the-job training (OJT) as best. Trainees tend to be more strongly motivated because retention in a job by the training employer at the higher skilled wage is more likely under OJT than hiring a worker with a skill obtained outside. 


\begin{abstract}
Recent research has shown that many students who leave school without basic reading and math skills can acquire these skills if the pedagogical approach combines basic skills training with technical skills training directly related to real jobs. This "situated learning" approach to basic skills instruction is particularly effective because it builds on knowledge that workers already have, and because it helps students to understand why learning the skills is useful to them. (Murnane \& Levy 1994: 77; Osterman \& Batt 1993; Bassi 1994; Keep, Mayhew \& Others 2002; Ananiadou, Jenkins \& Wolf 2004)
\end{abstract}

\title{
5.2 Training as a Necessary but not Sufficient Condition for Job Creation
}

Expenditure on training can decrease the need and therefore the total resource costs for other public initiatives that are redistributive in their goals. Besides expenditures to improve pupil performance and raise attendance in primary and secondary education through higher inputs, there are public works programmes, food subsidies, unemployment allowances, child welfare grants and the like. Any savings on these income transfers that might be caused by skills acquisition must be recorded as benefit items in a cost-benefit appraisal of the use of public funds in training provision.

By the same token, although lowered unemployment is a prominent target, and potentially an unambiguous benefit of any act of investment, training must be recognised to fulfil only one of the pre-requisites for net job creation. The other requirements for employment creation make up a formidable list. So claims for a significant employment gain from training expenditure on the implicit presumption that it is alone a sufficient condition must be treated with scepticism.

For a new job slot or unit increase in employment, what is required, besides in most cases (i) training of some kind, are (ii) paying the costs normally incurred of screening applicants; (iii) a work station made available or created by investment; (iv) financing a period of low productivity during the worker's initiation and integration into the firm or organisation; (v) a commitment to the worker on future employment and income stability; (vi) ruling relative prices of inputs and outputs in the given technology at which an extra 
job will be profitable; and (vii) an effective demand existing for the higher output from an additional worker. All these requirements must be satisfied simultaneously for net job creation. Merely to provide such a list calls into question the too easy presumption that successful training alone will create jobs, irrespective of other conditions to be met or of public sector programmes designed and funded for that purpose (Archer 1997).

\subsection{The Potential Conflict between Training Objectives}

Certain distinctions have to be kept clear in designing a new system. A training regime can aim at productivity goals or distributive goals, and possibly at both. These are not necessarily compatible. While higher individual productivity through skill upgrading raises wages it also raises economic distance between workers which makes for further inequality. Similarly, employers have to be the principal clients of the training system in place if a rise in average productivity is their main objective in skills investment. But with their profit-driven preference for training the high ability end among the available lowskill workers, inequality can be deepened by training. Thus, improving the labour market chances of the vulnerable segments of the population can be only an indirect goal at best. There is the added danger "that graduates of income-targeted [training] programs can be stigmatised and employers may avoid them" (Osterman \& Batt 1993: 459; Wolf 2002; Machin \& Stevens 2004).

In the same vein, enterprise-based training, usually initiated by employers and often paid for by them, has been charged with entrenching labour force segregation in industrial economies because of its tendency to neglect workers less educated, lower-skilled and women. Training is also claimed to widen the opportunity gap between those employed and those without a conventional job. "Training tends to be provided for capital-intensive rather than for labour-intensive activities, in big rather than in small enterprises, and, not surprisingly, in developing rather than in declining economic sectors" (OECD 1989: 52; Campbell et al 2001; Anandiadou, Jenkins \& Wolf 2004).

None of these complications mean that training should not be given the status of a merit good. This is a good or service to which citizens are accorded a certain right irrespective of their ability to pay. So when pursued as a social goal, access to training conceived as a merit good is made wider and more equal than is generally believed should be the case 
for the mainstream of goods and services (Holtham \& Kay 1994: 5). In South Africa this standpoint is held by at least two of the social partners in the formation of labour market and labour force policies, namely government and trade unions (although they may not use the language of merit goods). But the trade-offs needed for the implementation of such a policy must be faced squarely. This is particularly so if training schemes are eventually devised to perform the multiple function of achieving efficiency as well as redistribution. Trying to kill more than one bird with the same stone may yield no bird at all, as we argue below.

\subsection{The Monitoring Problems that Face State Initiatives in On-The-Job Training}

Public agencies must overcome major difficulties in monitoring training on-the-job, where skills are acquired, utilised and often certificated within the enterprise. For the reasons already mentioned but summarised here, (i) this OJT form of skills delivery tends to meet work requirements in production most closely; (ii) it generally remains the most up-to-date in acquired competencies because it reflects the skill requirements of new technology that is driven by profit goals; (iii) it is often more cost-effective than institution-based training variants, for example, in training institutes and colleges; and (iv) it is favoured by trainees because of the implicit, and sometimes explicit, commitment to post-training employment by the firm supplying the training on-the-job. There is no reason to believe these four features not to hold also in South Africa, at least in large firms. Once again, though, research results for local confirmation do not exist (Culpepper 2001; Keep, Mayhew \& Others 2002; Wolf 2002; World Bank 2005).

Formally speaking, organisational entities external to the training site and to the market can be modelled to do anything. But whether these are institutions that have evolved like employers' associations and labour unions, or are bodies established by legal statute for the purpose like state agencies or departments, any course of action to foster a stable training equilibrium must face the question of feasibility. In the current political climate in South Africa there is a strong predilection for state initiative and control in certain spheres of economic activity. Skills training is one. The underlying presumption though that motivates all such intervention is that enough information and sufficiently powerful instruments are available for politicians and bureaucrats to carry out any policy judged to be desirable in the pursuit of economics and political goals. 
But this may not be true in the training sphere. Severe information barriers face not only the contracting parties of trainees and employers, but also the policy-making as well as the policy-implementing units of government. It is necessary to recall here the earlier discussion of the moral hazard and adverse selection outcomes likely to occur with constrained or asymmetric information. State failures are potentially as likely as market failures for the common information deficiency reasons we discussed.

Certain probable consequences were mentioned earlier, but the following are not difficult to predict (Parsons 1990; Osterman \& Batt 1993; Lucas 1994; Lynch 1994; ILO 1995; Booth \& Snower 1996; Leuven 2005, Bassanini et al 2005).

i) To offer incentives to employers for on-the-job training is potentially wasteful of resources because the resulting outcomes cannot be monitored adequately. Even more serious, the future survival of the firm cannot be predicted.

ii) Projecting training requirements into the future, for example, to set up programmes in declining industries, or for first-time job-seekers, or remedial programmes for the unemployed, is subject to wide margins of error in the estimates. Therefore potentially low rates of return will be yielded on the costs incurred, as predicted about the general forecasting of skills needs (Heckman 1994; Lalonde 1995; Wolf 2002, 2004).

iii) To certify the value of training performed inside an enterprise is complicated and expensive, yet provision of a documented qualification is vital to trainee morale and effort. Both written and practical tests have to be externally set and externally marked to ensure objectivity and economy-wide currency. An employer providing the training cannot do so. In addition, this means that testing must be conducted by examiners who do not know candidates personally, under examination conditions, and so usually cannot be administered in the enterprise in which training of the candidates took place. To be effective, in other words, international experience demonstrates that "the system must be 'above suspicion of abuse'” (Prais 1990: 225; Booth \& Snower 1996; Wolf 2002; Keep, Mayhew et al 2002). 
iv) Given the large size of the co-ordination task required, the likelihood of failure is high. If that happens there is the probable emergence of autonomous spheres inside the training system to meet the immediate skill needs of firms, industries and regions. Contracting parties make private and horizontal agreements to overcome shortages. So paradoxically, attempts at control by the centre, which is the state at national or regional level, would then be weakened not strengthened by the centralisation of responsibility for implementation.

One additional observation about interventionist action by the state must be to emphasise that demonstrating the existence of market failure is by itself not sufficient justification for intervention by a state agency. First, the benefits from correcting the deficiency in training market processes must be weighed against the cost of raising the required funds for the new administrative tasks and possible subsidies required for the correction. This can be from a voluntary levy, dedicated tax on payroll or an allocation out of general taxation revenue. This is difficult but essential even if the cost-benefit answer is itself subject to a wide margin of error.

Secondly, state failure must be treated symmetrically. There must be similar expectation of possible failure, in view not only of the state's potential impotence to effect change but also of perverse outcomes from well-intentioned action (Parsons 1990; Hansen 1991; Drake 1991; Heckman 1994; Wolf 2004; Leuven 2005). Thirdly, to fund enterprise-based training which may occur anyway in the normal course of profit-seeking production, is to use public sector resources simply as transfer payments to the training firm. Their expenditure will thus not raise the net volume of training performed.

Finally, greater efficiency in the financing function of the state is likely to come by making finer distinctions and interventions at micro-level wherever that is feasible. One longstanding suggestion is for a branch of the state or a collective agency to fund only the fixed costs of OJT. These are the "start-up" functions like the assessment of training needs, curriculum design, instructional techniques, identifying and hiring competent instructors, and the logistical issues of timing, location and certification. The remaining expenditures are the marginal costs of training that are best left to the training firms, these being the costs of instruction, instruction materials, trainee pay and foregone output. (Bassi 1994) South African research initiated in pursuit of reform should address this possibility. 


\subsection{A System that Works as a System}

A mixed bag of constraints points to a final set of questions for local research and appraisal. First, as emphasised already our objective is a training equilibrium which is self-sustaining as well as efficient. It has to be an institutional hybrid, combining public and private domains of responsibility and authority and a stable funding regime. In South Africa currently, the absence of a system that works as a system makes it difficult for a single decision unit - potential trainee, firm, employer group, state agency - to move unilaterally from one set of training practices to another.

Second, raising the output of intermediate skills will have a limited effect on productivity if there are not accompanying reforms in the managerial utilisation of skill. This applies to production strategies and the organisation of work in firms, in state-owned enterprises or public corporations as they are known in South Africa, and in the civil service. How these new management skills and perceptions should be fostered by complementary policies poses challenges, but management innovations are an essential component of serious reform efforts (Dertouzos 1989; Ryan 1991; Lindley 1991; Keep, Mayhew et al 2002; Badroodien 2003; Black \& Lynch 2004).

Third, establishing appropriate incentive mechanisms was identified earlier as a key dimension of success. Not only must companies be induced to invest but so also must trainees. This is particularly true for first-time job seekers who have to incur the direct monetary and psychological costs of training, in addition to working for a period without full-time earnings, or by becoming net debtors. Small companies and their workforces have to overcome markedly severe constraints. Even the German Handwerk enterprises face similar problems (Soskice 1994).

In South Africa the SMME sector is widely singled out as posing special difficulties to policy-makers (Badroodien 2003; McGrath et al 2004; Kraak 2005). There is no magic formula to be found in the literature, other than encouraging "consortia of similar small firms to contract co-operatively with training providers to develop tailored curricula [that] can dramatically reduce the average cost" (Murnane \& Levy 1994: 77). This calls for a high measure of ingenuity in the institutional design and implementation of policy. 
Finally, nothing said in this section of the paper should be interpreted as scepticism about the desirability of greater investment in training, whichever way that is organized in our present labour market environment. The intention has been rather to temper wishful thinking and enthusiasm about a national training system as the panacea for many of our economic ills. Contrary to drawing a pessimistic conclusion, one truism that merits continual recollection is that long run real wage levels, indeed all increases in a society's standard of living, are paced by the rate of productivity growth. In an increasingly open economy like South Africa's, higher levels of employment in the end can be generated only through additional investment and a job-creation policy oriented towards new labour demands. For both these labour force outcomes an effective training equilibrium is a precondition that is indispensable. 


\section{High Level Skills Production in Tertiary Education}

As stated earlier, for the economic analysis of work competencies it is unrealistic to impose a hard and fast line between education and training. This is an institutional and therefore contingent division, not a logical one. What is at issue are all the learned abilities to perform productively significant actions. Formal schooling is a clear enough category because of its definite characteristics that have evolved over time with remarkable similarity in the majority of societies. Less tidy and exhaustive categories apply to what takes place after compulsory schooling. Acquisition of these further abilities occurs inside institutions like universities, technical colleges, vocational schools or industrial training institutes. Yet it also takes place outside such settings dedicated to the purpose, as in the vast amount of on-the-job training in all contemporary economies discussed earlier in this paper.

A weakness in local South African research into skills training is neglect of the simple complementary relationship between the competencies acquired up-stream in the school system and its effects on the success and profitability of downstream skill acquisition. This applies for instance, to apprenticeships or learnerships as well as the array of shorter training courses that workers undergo inside or outside companies. Learning begets learning is a strong generalisation that stands up to research scrutiny. The causal relationship referred to is also termed the self-productivity of investment or recursive productivity.

[Recursive productivity] embodies the idea that skills acquired in one period persist into future periods. It also embodies the idea that skills are self-reinforcing. For example, self-control and emotional security may reinforce intellectual curiosity and promote more vigorous learning of cognitive skills. [So] early investment in cognitive and non-cognitive skills lowers the cost of later investment by making learning at later ages more efficient" (Cunha, Heckman \& Others 2005: 5; Heckman 2005: 3).

If this proposition is reasonably well established, one of its implications is that at the level of national resource allocation for the production of human capital there is a tradeoff between schooling and post-school training. This presumption underlies this paper, although education below the tertiary level has been judged to fall outside the supplied 
brief and receives little attention here.

One observation about compulsory education is relevant. Efficiency considerations in South African education receive more attention now in the local research literature than a decade ago, although this is only the first step on the way to effective remedial policies. Immediately after the political changes of the 1990s official concern was primarily with matters of equity in the education system as a whole. But now we are told that in national discussions about educational spending, efficiency considerations have moved forward and there "is growing concern over the mismatch between expenditures and outcomes" (Seekings 2002: 3, Seekings 2001; Taylor, Muller \& Vinjevold 2003; Fiske \& Ladd 2004; Jansen 2005).

State expenditure on education in recent years has grown at about 8 per cent, slightly lower than the growth of state consolidated expenditure. But education as a spending category each year is still the largest single item in the national budget; at R92b out of $\mathrm{R} 472 \mathrm{~b}$ in 2006 it approaches 20 per cent. In some earlier years it has been up to 23 per cent. This total spending base excludes the payment of interest on national debt on the grounds that such payments do not represent strategic decisions by government about the allocation of state resources. Paying interest and paying off debt is a first call on revenue not a spending choice.

Turning to the production of high level skills by the higher education sector, a component of the brief for this paper, two questions will be addressed in a widely-ramifying field. First, how do government and tertiary institutions like universities and technical universities approach the task of setting enrolment numbers, course choices and content, as well as the mix of degrees on offer? Second, there is preliminary evidence of South African graduate unemployment being on the rise, so how is this seemingly paradoxical tendency to be explained?

The international literature demonstrates that the "idea that there is a simple, clear, linear relationship between the proportion of a particular national age cohort entering (or successfully completing) HE [Higher Education] and that country's economic performance is doubtful" (Keep \& Mayhew 2004: 299). There are a number of countries in recent times with above-average proportions of the population in tertiary education but which exhibit mediocre economic stability and growth, for instance, Egypt, New Zealand and Scotland. Conversely, Switzerland by most accepted criteria evidences consistent economic 
success but it has a small higher education sector compared to other countries, currently as well as when viewed historically.

It is tempting to approach our South African HE sector as facing unique choices because of our apartheid past in which there were deliberate efforts at pursuing a divided system. In terms of equity our tertiary sector's divisions are probably unusually wide. But when we examine its implications in the policy dimension, it turns out that in the contemporary world all departments of state charged with steering national universities face the same choices.

$\odot$ How is efficiency to be combined with equity where all societies contain class divisions that show up in disproportionate numbers of higher education students coming from upper income households?

$\odot$ What share of a degree or course cost should be born by graduates?

$\odot$ How is responsiveness to market signals by institutions to be reconciled with national goals set by governments? This issue applies specifically to the numbers admitted and the mix of subject and professional degrees on offer?

$\odot$ Universities claim chronic shortages of resources, so what funding criteria are appropriate for recognising not only the economic value of the high level human capital they produce but also the economic value of the research they conduct?

There is no evidence that these policy choices have been solved in South Africa. Three comments suffice. First, all local HE institutions are grappling with widespread failure at the school level because this generates negative impulses higher up the education scale in tertiary study. "Studies conducted in South Africa from 1998 to 2002 suggest that learners' scores are far below what is expected at all levels of the schooling system, both in relation to other countries (including other developing countries) and in relation to the expectations of the South African curriculum" (Taylor et al 2003: 41). Whether remedial action after exit from school can be an effective as well as efficient use of resources by 
universities and other tertiary institutions is not clear. Research work by Heckman and others already cited in this paper shows the task as formidable in the United States and other industrial countries containing sizeable immigrant populations low on the income and employment scales.

Second, official bodies charged with Higher Education (HE) policy formulation appear reluctant to decide how state steering can be combined with institutional autonomy in making decisions about screening entry and kinds of degree choices on offer. Also they fail to provide operational definitions of the goals they ascribe to the state.

The enrolment planning framework outlined in this document is...informed by three key factors. (i) The imperative to match enrolment plans with available resources to enable the higher education system to deliver on its teaching and research mandate. (ii) The need to ensure that enrolment plans are linked to national human resource and research priorities...[so that] any changes that result from the proposals in this document must take into account national priorities, in particular, in scarce skills fields such as teacher education and science, engineering and technology. (iii) The need to enhance quality, in particular, throughput and graduation rates (Department of Education 2005: 3-4).

In a similar vein, "It is clear from the Ministerial Statement.... that student enrolment planning should be based on the imperative to produce graduates with the skills and competencies necessary to meet the human resource needs of the country. As there has so far not been a comprehensive research picture generated of the exact 'needs structure' of South Africa's human resources development challenge, it might be important for the SEPHE [Student Enrolment Planning in Public Higher Education] enrolment planning model to be qualified in a manner that will enable its revision should our understanding of the former improve in coming years" (Higher Education South Africa 2005: 6). Neither of these documents explain how national "needs" and "priorities" are to be identified and quantified in practice when deciding, for example, which subject degrees should get higher subsidies per enrolled student than others. 
Third, there is still agitation for free tertiary education. Powerful political forces are pushing for much higher proportions of enrolment by black students, of which a large fraction will be in the financially needy category for a considerable time to come. Prima facie it seems paradoxical to require such students to pay a larger share of their study costs than has been the norm in past university financing. But there are plausible arguments to show that this is unavoidable if quality is to be maintained. Also it can be demonstrated that a mixed system of loans and bursaries is in line with international trends because it is acceptable on the grounds of both efficiency and distributive justice.

Successful graduates of any higher education system are, in their vast majority, members of the elite in all societies. Whatever their circumstances may be on entry, their subsequent earnings and job security over working lives of 40 years place them on the income scale higher by a multiple than the individual at the median level of income. Similarly their earnings are higher than the median tax payer who would otherwise have to fund the HE sector completely. As was asked during the Australian debate about setting up a national student loan scheme in the 1990s, "Why should bus drivers pay for all the education of future lawyers?" (West 1994: 10).

Lastly, there is preliminary evidence that graduate unemployment has risen in South Africa in recent years, see Table 6. If true, how is this trend to be reconciled with claims of high level skills shortages amongst the economically active population? This paper advances no specific answer because no research has addressed this question directly. But if significant levels of HE unemployment have emerged then this phenomenon can be compatible with one major contention in the paper. At the micro level where a worker's skills are matched with the requirements of a job, for success a large amount of specific information is required on both sides of a hiring contract. A worker may possess a conventionally described skill, have the documented accreditation to support that, and yet may be judged unsuitable by a potential employer. Quality deficiency and unsuitable personal characteristics may be the simple explanation. This is not an unusual circumstance by any means in all national labour markets, and it explains why information at the level of occupation is often of such limited use in identifying true labour market supply and demand magnitudes.

Bell \& Madula (2002: 119-120) raise a related question. It concerns the marked contrast between two major sectors' experience of skills availability in the 1990s. These are manufacturing and FIRE, comprising the finance, insurance, real estate and business services sector that employ large numbers of tertiary graduates. The difference between 
these sectors shows the high possibility of error in making unguarded generalisations about the magnitude of skills shortages across the board.

[T]he FIRE sector is a great deal more skills intensive than manufacturing as a whole. Furthermore, though the total labour force in FIRE was only one-third of that of manufacturing in 1993, the increase of employment of 'highly skilled' workers in FIRE in 1993-97 (27 802) was more than two-thirds greater than in manufacturing as a whole (16 288). The puzzle is this: if a shortage in the supply of skills, as such, is a binding constraint on the growth of manufacturing industry, then why was the output and employment growth performance of the FIRE sector, a far more skills-intensive sector, so vastly superior to that of manufacturing, especially in the 1990s? The relatively rapid...growth rates of the FIRE sector suggest that an inadequate supply of skills as such may not be the key reason for the stagnation of manufacturing. (emphasis added)

Table 6: Unemployment for Degreed Workers: African and White, 1995 and 2002

\begin{tabular}{|c|c|c|}
\hline & African & White \\
\hline \multicolumn{3}{|c|}{ Unemployment numbers } \\
\hline 1995 & 8834 & 5645 \\
\hline 2002 & 45959 & 13597 \\
\hline$\%$ Change & 420.25 & 140.87 \\
\hline \multicolumn{3}{|c|}{ Unemployment Rates } \\
\hline 1995 & $5.87(0.015)$ & $0.01(0.006)$ \\
\hline 2002 & $16.41(0.018)$ & $3.15(0.008)$ \\
\hline
\end{tabular}

Source: Bhorat 2004: 959, October Household Survey 1995 \& Labour Force Survey February 2002, university and technikon graduates. Standard Errors are in parenthesis, and are corrected for according to frequency weights, the primary sampling unit and sampling stratification. 


\section{Skills Importation and a South African Skills Training Equilibrium}

The current international literature concerns new responses and new modes of analyses about cross-border migration for economic motives. Nineteenth and early twentieth century movements on a large scale occurred also due to the search for superior economic opportunities, but the type of labour resources that migrated then was rather different. Also, other powerful motives came into play later, like family reunification. For this earlier wave of movement between countries a century ago three causal forces have been suggested: falling transportation costs due to investment in railways and steam ships; an expanded demand for low-skilled workers in agriculture and mining due to colonisation of new territories; and a growing need for unskilled urban workers with expanding industrialization in northern Europe and the United States (Chiswick 2005).

In the present $20^{\text {th }}$ and $21^{\text {st }}$ centuries wave of migration, in general the motive in the country of origin is still primarily economic, namely, disparities in wage opportunities across frontiers. Yet the motive in the typical economy of destination is now a mixed one. In industrial countries, particularly in Western Europe, it is a concern with the demographic aging of the labour force together with an increased relative demand for high-skilled workers due to technological change. These trends govern national attitudes and therefore policy. Whether an overall decline in labour supply due to aging is a realistic projection into a distant future is still being debated. Secondly, whether it warrants active immigrant replacement in industrial countries is a separate proposition also to be investigated. There is additionally the recent realisation that migrants, although liable to pay taxes, will themselves age in time and demand pensions and other benefits. If true on a large scale this means that only temporary relief in the rising dependency ratio can be obtained by migration (Migration Policy Group 2005: 5).

Yet the parallels between international experience and the South African situation apply to the potential opportunities afforded by deliberate, or policy-encouraged, high-skill immigration alongside the difficulties associated with undocumented in-migrating workers. These are illegal immigrants, the vast majority of whom enter destination countries like South Africa for economic more than political motives. They are not a concern of this paper, which is not to say that their net economic effect in our labour market will be negligible or even negative in the long-run. 
What is emphasised at considerable length in recent literature on economic migration is that labour market policy and migration policy, especially concerning the selection of temporary migrants into destination countries, should be integrated. Simply stated, this is not easily accomplished. The objectives of each set of state actions are not necessarily complementary when they pertain to skilled labour. In addition, the control of immigration is in accordance with a wider set of political criteria concerning actions perceived as in the national interest. This may easily clash with the sanctioned and facilitated inward movement of skilled labour to stimulate growth in particular enterprises and sectors.

For economy in exposition we list serially certain issues that arise in the regulation of inward migration by skilled individuals who are economically active.

- A potential policy of active skilled labour recruitment from source countries can learn a great deal, positive as well as negative lessons, from the prior experience of industrial countries. The following account sounds familiar to South African ears but perhaps it is too benign to fit local circumstances convincingly.

Institutional constraints on labour markets, high unemployment among the low-skilled and excess demand for the skilled workers broadly describes the predominant situation in the European Union, currently and in the longer-term future. A selective immigration policy that tends to avoid unskilled migrants and attract skilled foreign workers would, therefore, be a safe strategy to foster growth, increase demand for unskilled native workers, and be beneficial for all. For these reasons, migrants can be "good economic friends" to natives in the labour market. (Constant \& Zimmermann 2005: 96) 
- By consensus the information technology or computer revolution has not been skill neutral but has rather pushed up the productivity of high-skilled more than it has that of low-skilled workers. This is now a truism. "To provide some examples, computer engineers and programmers have been designing hardware and software that have displaced lower-skilled workers, whether through robots replacing assembly-line factory workers, electronic scanners replacing check-out clerks at retail establishments, or voicemail replacing answering clerks" (Chiswick 2005 :2). Whether this skill bias is temporary, meaning a transitory advantage to those with higher skills because they adapt more readily, or whether it is inherent in the technology and will persist, determines whether the widened payment differential is permanent. Alternatively, the differential will decline as the technology becomes familiar to a wider population, making investment in human capital less attractive. Which outcome is most plausible is still unclear.

- A number of industrial countries are either considering or have introduced temporary migration programmes (TMPs) in recent years; for example, in the USA, UK, Italy and Spain, "most of them within the framework of bilateral agreements with sending countries in Northern Africa and Latin America" (Ruhs 2005: 1). A key feature of them is that living and working in a receiving country under a TMP dispensation does not by itself provide an entitlement to stay permanently in that country.

- TMPs in general vary along a number of dimensions: (i) Mechanisms for regulating admission of temporary migrants can be either by quotas, by work-oriented permit fees, or simply non-interference by policy, i.e. a laissez-faire treatment of migrant admissions for economic motives. (ii) The specified level and characterisation of the skill type required in potential migrants. (iii) To fill sector-specific labour shortages, a TMP is normally issued for only one sector, although this requirement can be relaxed within limits. Such lifting of restrictions is to meet the mutual interests of the migrant, the employer and the state regarding other sectors diagnosed as facing excess demand for the identifiable skill in question. (iv) The duration and number of renewals of permits allowed are a clear decision variable in policy formation, presumably influenced by political motives alongside economic ones. (v) Conditions attached to TMPs span a wide range intended to protect existing workers in the receiving country. These include the specification of work for only one employer or sometimes a designated number but no more employers; rules of access to public services including welfare; the right to family visits or reunions; and stated penalties for both workers and employers for infringing conditions laid down in permit contracts. 
- Skill shortages in receiving countries result from acceleration in skill-biased technical change on the demand side, and from educational failure on the supply side. Skilled talent in countries of origin has been poached by major industrial country users - the practice of "screening-cum-cherry-picking" by firms and governments - using a range of incentives and institutional mechanisms. The recent application of ideas from the economics of information and incentives literature has helped distinguish (i) the various circumstances under which not only individual migrants gain but also the emergence of benefits for economically active workers who stay behind in the source country; (ii) the sign and magnitude of gains for the receiving economies can be estimated under differing assumptions about the ability of employers in Country A to screen potential immigrants in Country B efficiently; (iii) recognition of the importance of dimensions like sector agglomeration that cause productivity gains through the sharing of knowledge, teamwork and backward as well as forward linkages in the production chain; and (iv) the importance of the size of the sectors and the scale of activities that use skilled inputs. Smaller countries - measured by numbers in the labour force and their income levels - are not able to achieve the mass necessary to exploit skilled and talented labour efficiently. "There are clear educational thresholds [and] it is no accident that software sectors in developing countries have mostly emerged in [those] countries with ex ante, thick, skilled-labor markets" (Commander et al 2004: 262-3). India is probably the clearest example.

- A points system for selecting migrants is widely advocated. But there are problems to anticipate. In essence what has to be devised is a system of translation between knowledge of skills needs and a functioning admissions system. Should employers, the state or even immigrants themselves in some manner, exercise choice and authority? Does the average government have the capacity to run systems that have to remain responsive to changing economic conditions? Public servants and administrators are observers outside the labour market who would nonetheless have to know with reasonable accuracy the real short-term skills needs of the business community as well as of departments of government at different levels, of parastatals, and of non-profit organisations. In fact, to identify labour market needs is to track a moving target, with a proportion of shortages entirely transitory in practice, opening up and disappearing within the space of months.

Alternatively, is it more prudent to concentrate on knowledge of the human capital characteristics of migrants, like educational qualifications, certificated skills, work experience, age, gender, and language proficiency? This broader information can determine the probability of labour market success regardless of occupation, sector and 
specified job vacancies. The new migration literature is suffused with cautions about the costs associated with testing the realism of skill needs along with the individual qualifications of each applicant. "Most countries operate a mix of systems, experimenting with a multitude of instruments: economic needs tests, exemptions from economic needs tests, regularisation, temporary work permits, various types of quotas, points systems, geographically specific admission, job seeker visas, facilitated immigration for students, and more" (Migration Policy Group 2005: 1). 


\section{Conclusion}

This paper's aim is to place selected issues from the international literature on skills training in a perspective amenable to South African application. To assist policy-makers and researchers, it summarises the ways of thinking adopted by economists and policy-makers when faced with reform in other national educational and training systems. Some of the key ideas discussed are the following.

First, training and education are commodities with characteristics that militate against simple allocation through a market. They are in part public goods. This means that, like knowledge, more training or education for one person does not necessarily mean less for another. So people who free ride on such investments, using them for economic purposes but not paying their full costs, cannot be wholly excluded from their benefits. In addition, education and training have spill-over or external effects, as well as being constrained by asymmetrical information which inhibits free and mutually beneficial contracting between producers and consumers. Price signals are thus not efficient, and nor is the volume of investment in human capital likely to be at a social maximum.

The causes that contribute to these difficulties in market allocation are (i) the low frequency of purchase of skills training; (ii) the high penalties from making a mistaken choice; (iii) the limited ability to judge the quality of outcomes or know the direct links between inputs and outputs in human capital investment; and (iv) the substantial cost in changing the source of supply. For example, enrolment to acquire a skill can be in a training institute, FT college, university or technical university, as well as in on-the-job training in enterprises of diverse kinds. The literature on industrial countries shows the latter route for investing in skills as by far the most significant in quantitative terms. (Booth \& Snower 1996; Lynch \& Black 1998; Cunha, Heckman et al 2005; Bassanini et al 2005; Leuven 2005.)

Second, markets fail and governments fail, so the wisest policy is attempting to identify actions and institutions which minimise the extent of either kind of failure. This is a truism yet nonetheless difficult to achieve. Progress is unlikely to be furthered by applying a simple business metaphor to skills training and education, which entails "leaving it to the market"; or at the opposite extreme by presuming an all-knowing state with the capacity to reform at will. In general, the benefits from correcting a system distortion have always to be weighed against the costs of raising the resources required to do so. Piecemeal 
adaptation of this kind is unavoidable. So the challenge is to create conditions for its rational application in human capital investment.

Third, the case for the right amalgam of government and market in skill formation, or setting the economic borders of the state in this activity, has to rest on two pillars. These are an instrumental theory of how the mixed economy works, combining market forces with state intervention, and a set of fundamental principles based on value judgements. The first of these pillars warns that an economy is complex and may react perversely to actions which seem on the face of it to be welfare-increasing and therefore desirable. The second component, the underlying principles, make clear that there are inescapable trade-offs to be made. All good things do not go together, unfortunate as that may be in real world economies.

Too many protagonists in policy debates presume that only instrumental considerations need play a role in deciding what policy actions are best to pursue. On the contrary, we are firmly in the business of comparing imperfect institutions and we cannot avoid sacrificing one goal for another. That means resort to underlying principles that are inherently normative. For instance, in the real world of second best when deciding on policy we are faced with the choice between greater consultation and accountability at the price of lowered decision-making efficiency. That is a simple but realistic example of a trade-off.

Passionate advocacy of either an omniscient state or of private decision-taking via the market mechanism in every sphere of social and economic activity on presumptive grounds is what we do not need. Applied to training as well as educational reform, this point has been implicit throughout this discussion of human capital investment.

Finally, the complexity of the issues regarding the role of skills training and education in the development process has been stressed throughout this paper. That explains the deliberately qualified tone of much of this discussion. The passage below, quoted a second time, illustrates the information detail inherent in strategic decisions about skills investment. It is a reminder why a cautious stance in drawing conclusions for policy is unavoidable in this research area. 
Education and training as policy vehicles are limited in many ways - for example, in the lag between schooling and greater productivity, the loose linkage between skills of workers and skill demands of jobs, and the uneven and uncertain responses of managers and firms to uncertainty. Arguments for increased education hinge primarily on bringing all of the population to minimal levels of literacy and additional schooling for the less well-educated because education and training appear to minimize the adverse consequences of technological change for workers, and workers with such training and education adapt to change better and quicker...Curriculum planning in the face of uncertainty should rely on curriculum diversification and periodic review aimed at adjusting available programs to demand. Thus, within modest limits, the research on technological change and skill requirements informs education and training policy, and within modest limits, education and training can be expected to inform and solve human problems associated with technological change. (Spenner 1995: 128-9, italics added.) 


\section{References}

Acemoglu, D. \& Pischke, J. 1999 The structure of wages and investment in general training. Journal of Political Economy 107, 539-572

Acemoglu, D. 2002 Technical change, inequality, and the labor market, Journal of Economic Literature 40, 7-72

Ananiadou, K., A. Jenkins \& Wolf, A. 2004 Basic skills and workplace learning: what do we actually know about their benefits?, Studies in Continuing Education 26, 289308

Ananiadou, K., A. Jenkins \& Wolf, A. 2003 The benefits to employers of raising workforce basic skills levels: A review of the literature, Research Review, National Research \& Development Centre, London.

Archer, S. 1997 The finance and organisation of training: Theoretical issues in South African perspective. South African Network for Economic Research Working Paper 3, Cape Town: SANER.

Archer, S. 2003 Education and economic development: Resources, institutions, curriculum content and training in the search for policy guidelines in South Africa, Research Paper for National Business Initiative, Johannesburg.

Arnal, E., Ok, W. \& Torres, R. 2001 Knowledge, work organisation and economic growth. OECD Occasional Paper No. 50: Labour Market and Social Policy, Paris: OECD.

Arulampalam, W., Booth, A. \& Bryan, M. 2003 Training in Europe. IZA Discussion Paper No. 933, Bonn: IZA.

Ashton, D., Maguire, M. \& Sung, J. 1991 Institutional structures and the provision of intermediate level skills: Lessons from Canada and Hong Kong. In P. Ryan (Ed.), International comparisons of vocational education and training for intermediate skills. London: Falmer Press. 
Asplund, R. \& Salverda, W. 2004 Introduction: Company training and services with a focus on low skills, International Journal of Manpower 25, 8-16

Badroodien, A. 2005 Enterprise training in post-apartheid South Africa, Journal of Education and Work 18, 85-110

Bassanini, A. \& Ok, W. 2004 How do firms' and individuals' incentive to invest in human capital vary across groups? OECD Social, Employment and Migration Working Paper. Paris: OECD.

Bassanini, A., Booth, A. L., Brunello, G., De Paola, M. Leuven, E. 2005 Workplace training in Europe, IZA Discussion Paper 1640, Bonn: IZA.

Bassi, L. 1994 Workplace Education for hourly workers, Journal of Policy Analysis and Management 13, 55-74

Bean, C. 1994 European unemployment: A survey, Journal of Economic Literature 32, 573619

Becker, G. 1964 Human capital, New York: National Bureau of Economic Research.

Bhorat, H. 2004 Labour market challenges in the post-apartheid South Africa, South African Journal of Economics 72, 940-977

Bhorat, H. \& Lundall, P. 2004 Employment, wages and skills development: Firm-specific effects - Evidence from a firm survey in South Africa, South African Journal of Economics 72, 1022-1055

Black, S. \& Lynch, L. 2004 What's driving the new economy?: The benefits of workplace innovation, Economic Journal 114, F97-F116

Blaug, M. 1995 The wage contract and education. In M. Carnoy (Ed), International Encyclopedia of the Economics of Education, Oxford: Pergamon, pp 44-52 
Blondal, S., Field, S. \& Girouard, N. 2002 Investment in human capital through postcompulsory education and training: selected efficiency and equity aspects. OECD Economics Department Working Paper No. 333

Blundell, R., Dearden, L., Meghir, C. Sianesi, B. 1999 Human capital investment: The returns from education and training to the individual, the firm and the economy. Fiscal Studies 20 (1), 1-23

Booth, A. \& Bryan, M. 2005 Testing some predictions of human capital theory: New training evidence from Britain. Review of Economics and Statistics 87, 391-394

Booth, A. \& Snower, D. (Eds) 1996 Acquiring skills: Market failures, their symptoms and policy responses, Cambridge: Cambridge University Press.

Brunello, G. \& De Paola, M. 2004 Market failures and the under-provision of training, CESIFO Working Paper No. 1286

Cantwell, J. 1999 Innovation as the principal source of growth in the global economy. In Archibugi, D. (Ed), Innovation Policy in a Global Economy, Cambridge: Cambridge University Press, pp 225-241.

Campbell, M., Baldwin, S., Johnson, S., Chapman, R., Upton, A., Walton, F. 2001 Skills in England 2001. Report: Leeds Metropolitan University, Leeds: UK.

Carneiro, P. \& Heckman, J. 2003 Human capital policy. NBER Working Paper 9495, Cambridge, Massachusetts: National Bureau of Economic Research.

Chiswick, B. 2005 High skilled immigration in the international arena, IZA Discussion Paper No. 1782, Bonn: IZA (Institute for the Study of Labour).

Claessens, S. 2005 Access to financial services: A review of the issues and public policy objectives. World Bank Policy Research Working Paper 3589

Constant, A. \& Zimmermann, K. 2005 Immigrant performance and selective immigration policy: A European perspective, National Institute Economic Review 194, 94105. 
Cohen, J., Dickens, W. \& Posen, A. 2001 Have new human-resource management practices lowered the sustainable unemployment rate? In A. Kruger \& R. Solow (Eds.), The roaring nineties: Can full employment be sustained? New York: Russell Sage, pp. $219-259$

Commander, S., Kangasniemi, M. \& Winters, L. 2004 The brain drain: curse or boon?: a survey of the literature. In R. Baldwin \& L. Winters (Eds.), Challenges to globalization, Chicago: University of Chicago Press, pp 237-278

Crafts, N. 2004 Globalisation and economic growth: a historical perspective, The World Economy 27, 45-58

Crouch, C., Finegold, D. \& Sako, M. 1999 Are skills the answer? Oxford: Oxford University Press.

Culpepper, P. 2001 Employers, public policy, and the politics of decentralized cooperation in Germany and France. In P. Hall \& D. Soskice (Eds.) Varieties of capitalism Oxford: Oxford University Press, pp. 275-306

Cunha, F., Heckman, J., Lochner, L. \& Masterov, D. V. 2005 Interpreting the evidence on life cycle skill formation, NBER Working Paper 11331, Cambridge, Massachusetts: National Bureau of Economic Research.

Cyert, R. \& Mowery, D. (Eds.) 1988 The impact of technological change on employment and economic growth, Cambridge, Massachusetts: Ballinger.

Department of Education 2005 Student enrolment planning in public higher education, Pretoria: Department of Education.

Department of Labour 2005 State of skills in South Africa, 2005. Pretoria: Department of Labour.

Dertouzos, M. 1989 Made in America: regaining the productive edge, Cambridge, Massachusetts: MIT Press. 
Dixit, A. 2002 Incentives and organizations in the public sector, Journal of Human Resources $37,696-727$

Drake, K. 1991 Interventions in market financing of training in the European Community. In P. Ryan (Ed.), International comparisons of vocational education and training for intermediate skills, London: Falmer Press.

Edwards, L. 2003 Trade, technology and employment in South Africa, Trade \& Industry Monitor 23, 11-15

Ellis, S. 2003 Anticipating employers' skills needs: The case for intervention, International Journal of Manpower 24, 83-96

Evenson, R. \& Westphal, L. 1995 Technological change and technology strategy. In J. Behrman \& T. Srinivasan (Eds.), Handbook of development economics, Amsterdam: Elsevier, pp 2209-2299

Feldstein, M. 2003 Why is productivity growing faster? NBER Working Paper 9530. Cambridge, Massachusetts: National Bureau of Economic Research.

Fella, G. 2005 Termination restrictions and investment in general training. European Economic Review 49, 1479-1499

Feuer, M., H. Glick \& A. Desai 1991 Firm financed education and specific human capital: a test of the insurance hypothesis. In D. Stern \& J. Ritzen (Eds.), Market failure in training? New economic analysis and evidence on training of adult employees. Berlin: Springer-Verlag, pp. 41-59

Finegold, D. \& Soskice D. 1988 The failure of training in Britain: analysis and prescription. Oxford Review of Economic Policy 4, 21-53

Fiske, E. \& Ladd, H. 2002 Financing schools in post-apartheid South Africa, Typescript, School of Economics, University of Cape Town. 
Forth, J. \& Mason, G. 2006 Do ICT skill shortages hamper firms' performance? Evidence from UK benchmarking surveys. Working Paper, National Institute of Economic and Social Research, London.

Freeman, R. 2002 The labour market in the new information economy. Oxford Review of Economic Policy 18, 288-305

Fuller, A. \& Unwin, L. 2003 Creating a "modern apprenticeship": a critique of the UK's multisector, social inclusion approach. Journal of Education and Work 16, 5-25

Gasskov, V. (Ed.) 1994 Alternative schemes of financing training, Geneva: International Labour Office.

Gleeson, D. \& Keep, E. 2004 Voice without accountability: the changing relationship between employers, the state and education in England, Oxford Review of Education, 30 , $37-63$

Green, F., Ashton, D., James, D. \& Sung, J. 1999 The role of the state in skill formation: evidence from the Republic of Korea, Singapore, and Taiwan, Oxford Review of Economic Policy 15, 82-96

Greenhalgh, C. 2002 Does an employer training levy work? The incidence of and returns to adult vocational training in France and Britain. Fiscal Studies 23, 223-263

Hansen, W. 1991 Nonmarket failure in government training programs. In D. Stern \& J. Ritzen (Eds.) Market failure in training? New economic analysis and evidence on training of adult employees. Berlin: Springer-Verlag, pp. 215-233

Hart, P. \& Shipman, A. 1991 Financing training in Britain, National Institute Economic Review 136, 77-85

Hashimoto, M. 1994 Employment-based training in Japanese firms in Japan and in the United States: Experiences of automobile manufacturers. In L. Lynch (Ed.), Training and the private sector: International comparisons. Chicago: University of Chicago Press. 
Heckman, J. 2005 Lessons from the technology of skill formation. NBER Working Paper 11142. Cambridge, Massachusetts: NBER.

Heckman, J. 1994 Is job training oversold? The Public Interest 115, 91-115

Heckman, J. \& Masterov, D. 2004 Skill policies for Scotland, IZA Discussion Paper No. 1444, Bonn: IZA.

Heijke, H. (Ed) 1994 Forecasting the labour market by occupation and education, Dordrecht: Kluwer.

Higher Education South Africa (HESA) 2005 Perspectives on the report: Student enrolment planning in public higher education, Pretoria: Department of Education.

Hoekman, B. \& Javorcik, B. 2004 Policies facilitating firm adjustment to globalization, Oxford Review of Economic Policy 20, 457-473

Holtham, G. \& Kay, J. 1994 The assessment: institutions of policy, Oxford Review of Economic Policy 10, 1-16

Hopkins, M. 2002 Labour market planning revisited, Basingstoke: Palgrave Macmillan.

International Labour Office 1995 World labour report 8, Geneva: ILO.

Jacobson, L., LaLonde, R. \& Sullivan, D. 2005 Is retraining displaced workers a good investment? Federal Reserve Bank of Chicago Economic Perspectives 29, 47 66

Jansen, J. 2005 Does money matter? Towards an explanation for the relationship between spending and performance in education in South Africa. Working Paper, Institute for Justice and Reconciliation, Cape Town.

Jeong, J. 1995 The failure of recent state vocational training policies in Korea from a comparative perspective, British Journal of Industrial Relations 33, 237-252. 
Katz, E. \& Ziderman, A. 1990 Investment in general training: the role of information and labour mobility, Economic Journal 100, 1147-1158

Keep, E. 1991 The grass looked greener - some thoughts on the influence of comparative vocational training research on the UK policy debate. Ch. 1 in International comparisons of vocational education and training for intermediate skills. (ed. P. Ryan) London: Falmer Press.

Keep, E., K. Mayhew, SKOPE \& Mark Corney MC Consulting 2002 Review of the evidence on the rate of return to employers of investment in training and employer training measures, SKOPE Research Paper No. 34

Kraak, A. 2005 Human resources development and the skills crisis in South Africa, Journal of Education and Work 18, 57-83

Lalonde, R. 1995 The promise of public sector-sponsored training programs, Journal of Economic Perspectives 9, 149-168

Layard, R., Nickell, S. \& Jackman, R. 1991 Unemployment: Macroeconomic performance and the labour market, Oxford: Oxford University Press.

Leuven, E. 2005 The economics of private sector training: a survey of the literature, Journal of Economic Surveys 19, 91-111

Lindbeck, A. 2005 Sustainable social spending. CESIFO Working Paper No. 1594

Lindley, R. 1991 Interactions in the markets for education, training and labour. In P. Ryan (Ed.), International comparisons of vocational education and training for intermediate skills, London: Falmer Press.

Lucas, R. 1994 The impact of structural adjustment on training needs, International Labour Review 133, 677-694.

Lundall, P. 2005 Skills development for the employed and the unemployed in South Africa: a dialogue for challenging times, NEDLAC Community Constituency Paper. 
Lynch, L. (Ed) 1994 Training and the private sector: international comparisons, Chicago: University of Chicago Press.

Lynch, L. 2005 Job loss: bridging the research and policy discussion. IZA Discussion Paper No. 1518 , Bonn.

Lynch, L. \& Black, S. 1998 Beyond the incidence of employer-provided training. Industrial and Labor Relations Review 52, 64-81

Machin, S. 2006 Social disadvantage and education experiences. OECD Social, Employment and Migration Working Papers No. 32

Machin, S. \& Stevens, M. 2004 The assessment: education, Oxford Review of Economic Policy 20, 157-172

Maki, T. Yotsuya, K. \& Yagi, T. 2005 Economic growth and the riskiness of investment in firm-specific skills. European Economic Review 49, 1033-1049

Marsden, D. \& Ryan, P. 1991 Initial training, labour market structure and public policy: intermediate skills in British and German industry. In P. Ryan (Ed.), International comparisons of vocational education and training for intermediate skills. London: Falmer Press.

McGrath, S. (Ed.) 2004 Shifting understanding of skills in South Africa: Overcoming the historical imprint of a low skills regime. Pretoria: HSRC.

Mclntosh, S. \& Vignoles, A. 2001 Measuring and assessing the impact of basic skills on labour market outcomes. Oxford Economic Papers 53, 453-481

Migration Policy Group 2005 Immigration as a labour market strategy: European and North American perspectives. Brussels: Migration Policy Group.

Murnane, R. \& Levy, F. 1994 Comment: stimulating employer-provided general training, Journal of Policy Analysis and Management 13, 75-81

OECD 1989 Structural adjustment and economic performance, Paris: OECD. 
Oosthuizen, M. 2005 The post-apartheid labour market: 1995-2004, DPRU (Development Policy Research Unit) Working Paper 06/103. University of Cape Town: DPRU.

Osterman, P. \& Batt, R. 1991 Employer-centred training for international competitiveness: Lessons from state programs. In P. Ryan (Ed.), International comparisons of vocational education and training for intermediate skills. London: Falmer Press.

Oulton, N. \& Steedman, H. 1994 The British system of youth training: A comparison with Germany. In L. Lynch (Ed.), Training and the private sector: International comparisons, Chicago: University of Chicago Press.

Parsons, D. 1990 The firm's decision to train. In L. Bassi \& D. Crawford (Eds.), Labor economics and public policy, Research in Labor Economics, Vol. 11, Greenwich, Connecticut: JAI Press.

Pichler, E. 1993 Cost-sharing of general and specific training with depreciation of human capital, Economics of Education Review 12, 117-124

Pischke, J-S. 2005 Comments on "Workplace training in Europe" by Bassanini et al. Typescript, London School of Economics.

Prais, S. 1990 Productivity, education and training, London: National Institute of Economic and Social Research.

Ritzen, J. 1991 Market failure for general training and remedies. In D. Stern and J. Ritzen (Eds), Market failure in training? New economic analysis and evidence on training of adult employees. Berlin: Springer-Verlag.

Rodrik, D. 2004 Industrial policy for the twenty-first century, Typescript, Kennedy School of Government, Harvard University.

Ruhs, M. 2005 The potential of temporary migration programmes in future international migration policy. Global Commission on International Migration. 
Rumberger, R. 1995 Technological change and the demand for educated labor. In M Carnoy (Ed.), International Encyclopedia of Economics of Education. Oxford: Pergamon Press, pp 217-222

Ryan, P. 1991 Introduction: comparative research on vocational education and training. In P. Ryan (Ed.) International comparisons of vocational education and training for intermediate skills. London: Falmer Press.

Ryan, P. 2001 The school-to-work transition: A cross-national perspective, Journal of Economic Literature 39, 34-92

Ryan, P. \& Unwin, L. 2001 Apprenticeship in the British "training market". National Institute Economic Review 178, 99-114

Rychen, D. \& Sagalnik, L. 2003 Key competencies for a successful life and a well-functioning society, Cambridge, Massachusetts: Hogrefe \& Huber.

Sako, M. \& Dore, R. 1988 Teaching or testing: the role of the state in Japan, Oxford Review of Economic Policy 4, 72-81

SASOL 2004 Total stakeholders initiative: Project Turbo, artisan resources, Sasolburg: SASOL.

Seekings, J. 2002 Indicators of performance in South Africa's public school system, Centre for Social Science Research Working Paper No. 10, University of Cape Town.

Seekings, J. 2001 Making an informed investment: improving the value of public expenditure in primary and secondary schooling in South Africa, Report for Parliament of South Africa, Standing Committee on Public Accounts.

Soskice, D. 1994 Reconciling markets and institutions. In L. Lynch (Ed.), Training and the private sector: International comparisons. Chicago: University of Chicago Press.

Soskice, D. 1993 Social skills from mass higher education: rethinking the company-based initial training paradigm. Oxford Review of Economic Policy 9, 101-113 
South Africa 2005 State of skills in South Africa 2005. Pretoria: Department of Labour.

Spenner, K. 1995 Technological change, skill requirements, and education: The case for uncertainty. In D. Bills (Ed.), The new modern times: factors reshaping the world of work, Albany: State University of New York Press.

Stern, D. \& Benson, C. 1991 Firms' propensity to train. In D. Stern \& J. Ritzen (Eds.), Market failure in training? New economic analysis and evidence on training of adult employees, Berlin: Springer-Verlag.

Stevens, M. 1994 A theoretical model of on-the-job training with imperfect competition, Oxford Economic Papers 46, 537-562

Stiglitz, J. 1989 Financial markets and development. Oxford Review of Economic Policy 5, $55-68$

Stiglitz, J. 1992 Capital markets and economic fluctuations in capitalist economies. European Economic Review 36, 269-306

Taylor, N., Muller, J. \& Vinjevold, P. 2003 Research and systemic school reform in South Africa, Cape Town: Pearson Education.

Temple, J. 2001 Growth effects of education and social capital in the OECD countries, OECD Economic Studies 31, 57-97

Temple, J. 2002 The assessment: The new economy. Oxford Review of Economic Policy $18,241-264$

West, E. 1994 Britain's student loan system in world perspective: A critique. London: Institute of Economic Affairs.

Woessmann, L. 2006 Efficiency and equity of European education and training policies. CESIFO Working Paper No. 1779.

Wolf, A. 2002 Does education matter?, London: Penguin Books. 
Wolf, A. 2004 Education and economic performance: Simplistic theories and their policy consequences, Oxford Review of Economic Policy 20, 315-333

Woolard, I., Kneebone, P. \& Lee, D. 2003 Forecasting the demand for scarce skills, 20012006. In HSRC Human resources development 2003, Pretoria: HSRC.

World Bank 2005 South Africa: An assessment of the investment climate. Washington: World Bank Private Sector Group, 1-145 